\title{
OPEN Extraction of ingredients from tea leaves using oxidative enzymatic reaction and optimization of extraction conditions
}

\author{
Rasool Pelalak ${ }^{1,2}$, Afrasyab Khan ${ }^{3}$, Masoud Habibi Zare ${ }^{4}$, Mohammad Hasan Sadeghi' ${ }^{4}$ \& \\ Azam Marjani ${ }^{5,6 \bowtie}$
}

Peroxidase (POD) and polyphenol oxidase (PPO) are used as biocatalyst in many processes such as oxidization reactions, wastewater treatment, phenol synthesis and so on. The purpose of current study is enzymes extraction from biomass (tea leaves) as well as evaluation of their activation. Different parameters including temperature, buffer concentration, buffer type, buffer/tea leaves ratio, addition of high molecular weight polymers and emulsifiers, and pH were optimized in order to obtain the highest enzymes activity. Response Surface Methodology (RSM) procedure is employed for statistical analysis of enzymes extraction. It is understood from the result that PPO and POD possess the highest activity at temperatures of $25^{\circ} \mathrm{C}$ and $50^{\circ} \mathrm{C}, \mathrm{pH} 7$ and 5 , buffer molarity of 0.1 , and 0.05 , buffer/tea leaves ratio $=5$ for both, contact time $=20 \mathrm{~min}$ and $10 \mathrm{~min}$, and presence of $6 \%$ and $3 \%$ PVP, $5 \%$ and $0 \%$ Tween 80 for PPO and POD, respectively. Amounts of highest activity for PPO and POD biocatalysts were calculated $0.42 \mathrm{U} / \mathrm{mL}$ and $0.025493 \mathrm{U} / \mathrm{mL}$, respectively. Moreover, the entire inactivation of PPO took place after $30 \mathrm{~min}$ at $40^{\circ} \mathrm{C}$ and $60^{\circ} \mathrm{C}$ and $20 \mathrm{~min}$ at $80^{\circ} \mathrm{C}$. However, POD lost $35 \%$ of its activity after $30 \mathrm{~min}$ at $40^{\circ} \mathrm{C}$ and $60^{\circ} \mathrm{C}$. The amount of $6 \%$ POD activity was kept after $45 \mathrm{~min}$ at $80^{\circ} \mathrm{C}$. Generally, it was indicated that POD was more resistant to thermal treatment than PPO.

Extraction of enzyme from various sources and its application as a biocatalyst is one of the important achievements in the field of biochemical industry ${ }^{1-12}$. PPO enzyme is known one of the most prominent copper-containing biocatalysts possessing a great potential to catalyse two various reactions consisting of (1) o-diphenols to o-quinones oxidation and molecular oxygen, and (2) the o-hydroxylation of monophenols to o-diphenols ${ }^{13,14}$. This enzyme plays an indisputable role in the appropriate performance of different organs of human body (i.e. eye/skin melanization), and browning the agricultural crops (i.e. fruits ${ }^{15-17}$. POD is able to be extensively used in various applications such as water/wastewater industry (i.e., wastewater treatment), phenolic components' degradation process, and medical-related kits to diagnose diseases. The classification of POD biocatalyst into classes I, II and III may be done according to its existing sources ${ }^{18,19}$. PPO is existed in different amounts in living organisms (i.e., fungi, insects and mammals). The aforementioned biocatalyst is localized freely in the cytosol in plants ${ }^{20}$. POD is regarded as an important biocatalyst, which its presence/activity plays a momentous role in the lignification process of plants ${ }^{17,18,21}$.

Extraction, purification and characterization process of PPO and POD has been of tremendous attention in disparate agricultural crops (i.e. vegetables) because of the incontrovertible significance of enzymatic browning in food technology. Various advanced separation techniques have been recently developed for chemical/ biochemical applications including membranes ${ }^{22-29}$, adsorption ${ }^{30-37}$, and solvent extraction ${ }^{38}$. The mentioned methods can be utilized for extraction of enzymes. In a research, Khajeh et al. developed an instant method to pre-concentrate the trace amount of methylene blue from water using silver nanoparticles. They proved that

\footnotetext{
${ }^{1}$ Institute of Research and Development, Duy Tan University, Da Nang 550000, Vietnam. ${ }^{2}$ Faculty of Environmental and Chemical Engineering, Duy Tan University, Da Nang 550000, Vietnam. ${ }^{3}$ Department of Hydraulics and Hydraulic and Pneumatic Systems, Institute of Engineering and Technology, South Ural State University (SUSU), Lenin Prospect 76, Chelyabinsk, Russian Federation 454080. ${ }^{4}$ Department of Chemical Engineering, Isfahan University of Technology, 84156-83111 Isfahan, Iran. ${ }^{5}$ Department for Management of Science and Technology Development, Ton Duc Thang University, Ho Chi Minh City, Vietnam. ${ }^{6}$ Faculty of Applied Sciences, Ton Duc Thang

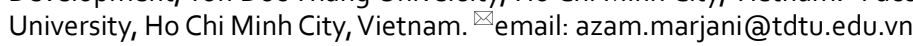


considering the optimum operational conditions, the detection limit, relative standard deviation and the linear range were achieved $15.0 \mathrm{mg} \mathrm{L}^{-1}$, less than $2.7 \%$ and between 0.07 and $1.0 \mathrm{mg} \mathrm{L}^{-1}$ with a R-squared of 0.996 , respectively ${ }^{39}$. Jain et al. experimentally investigated the amount of POD extraction from potato and cabbage applying supercritical $\mathrm{CO}_{2}$. They concluded that the extraction process of POD at a specific operational condition $\left(\mathrm{T}=40^{\circ} \mathrm{C}\right.$ and $\left.\mathrm{P}=10 \mathrm{MPa}\right)$ is considerably encouraging for use in remediation ${ }^{40}$. Panadare et al. applied the three-phase partitioning procedure with the aim of evaluating the extraction trend of the POD from bitter gourd waste. To do this, they used dimethyl carbonate as an organic phase. They have concluded from their investigation that the purity of POD biocatalyst was 4.84 fold at optimum source concentration $\left(0.15 \mathrm{~g} \mathrm{~mL}^{-1}\right)^{41}$. Khajeh and Gharan applied the zinc oxide nanoparticles-chitosan as an adsorbent to extract organic compounds (i.e. citric and tartaric) from biological samples. They corroborated that the optimum process conditions could be occurred when the $\mathrm{pH}$ value of solution $=10$, adsorbent mass $=0.5 \mathrm{~g}$, eluents volume $=2.5 \mathrm{~mL}$, sample flow rate $=2 \mathrm{~mL} \mathrm{~min}^{-1}$ and eluent flow rate $=3 \mathrm{~mL} \mathrm{~min}{ }^{-142}$.

Reverse micelles method is known as a noteworthy technique, which is widely employed to extract PPO biocatalyst from apple skin ${ }^{43}$. Batista et al. conducted an experimental investigation to assess the extraction efficiency of PPO biocatalyst from ripe and unripe fruits such as Solanum lycocarpum. They perceived the superiority of unripe fruits in terms of activity compared to ripe fruits ${ }^{15}$. Up to the knowledge of the authors, very few papers evaluated the extraction as well as statistical analysis of PPO and POD biocatalysts from green tea as biomass. Therefore, future investigations about this scope seem to be necessary and beneficial for valorization of biomass ${ }^{17}$.

The principal objective of this article is to evaluate the extraction amount of POD and PPO enzymes from Iranian tea leaves accompanying with studying the analysis and assessment of activity at disparate operational circumstances. Optimization of the extraction procedure to achieve pure enzymes is performed using RSM technique. This research paper is the molecular extraction of enzyme. Due to the existence of different variables including Temperature, Buffer $\mathrm{pH}$, Buffer to tea leave ratio, extraction time, Buffer molarity, PVP content, and Tween 80 concentration, this work can be regarded as one of the most complex experimental designs in the field of extraction, which has been done with great success to improve the process efficiency.

\section{Results and discussion}

Influence of the solvent type. The influence of some momentous parameters such as buffer type, water, and hexane on the performance of PPO and POD extraction in the $\mathrm{pH}$ values between 4 to 9 is illustrated in Fig. $1 \mathrm{~A}$ and $\mathrm{B}$. It is obvious from the results that by applying glycine and acetate as chemical solvents, the highest amount of activities of PPO and POD $(0.3$ and $0.015 \mathrm{U} / \mathrm{ml})$ was achieved. As can be seen in Fig. 1B, a general decrement in the activity of POD takes place, which is justified due to the application of buffer solutions with greater $\mathrm{pH}$ value. Moreover, by using non-buffer solutions as solvent, the activity of both PPO and POD biocatalysts declines considerably. Based on the observations, the authors found out that the utilization of buffer to extract PPO and POD biocatalysts seems to be more reasonable. Significant sensitivity of biomaterials to hydrogen/hydroxide ions is considered as the second justification of using buffer. The occurrence of reaction between the aforementioned ions negatively affects the structure of proteins and biomaterial. Additionally, it is observed from the figures that the amount of activity for PPO is almost 10 times POD.

Influence of operating conditions on biocatalysts activity. Response level Methodology (BoxBehnken) is employed in this article to achieve the optimum circumstances for 7 parameters through a set of minimum required experiments. The implemented DoE (Design of Experiment) was performed on the basis of Box-Behnken method. The application of abovementioned technique eventuates in decreasing the number of experiments from 152 to 62 . Table 1 renders the detailed specifications of the experiments and enzymes activity design based on Box-Behnken method. It is seen from the table that the highest amounts of PPO and POD activities are 0.42 and $0.025493 \mathrm{U} / \mathrm{mL}$, respectively.

Influence of each parameter on activity amount of both biocatalysts (PPO and POD) is computed and shown in Table 2. It can be seen that the temperature has the highest impact on the PPO and POD activities and the second order is allocated to the buffer $\mathrm{pH}$ of buffer solution. It was also concluded that other parameters such as the buffer-to-mass of tea ratio, contact time, and PVP content don't have a significant influence on the PPO activity according to the analysis of variance (ANOVA) calculation ${ }^{17}$. Also, The ANOVA fixes the relative effect of error (REE) at $0.03 \%$ and up to $0 \%$ for PPO and POD, respectively. REE means that the influences of other parameters not included in the analysis and any unintentional discrepancies were considered in optimization.

According to Response 1, the F-value of 106.73 illustrates the significance of the model. P-values less than 0.05 reveal that the model terms are considered as significant. As such, B, C, D, E, F, AB, AC, AD, BD, BE, BG, $\mathrm{CD}, \mathrm{DE}, \mathrm{DF}, \mathrm{DG}, \mathrm{EG}, \mathrm{A}^{2}, \mathrm{C}^{2}, \mathrm{~F}^{2}, \mathrm{G}^{2}$ are known as the important terms of model. Values higher than 0.1 indicate the insignificance of model terms. The Lack of Fit F-value of 1.14 shows that it is not significant related to the pure error. There is a $48.58 \%$ chance that a Lack of Fit F-value at this quantity might happen because of noise. The estimated $R^{2}$ value of 0.9576 is in acceptable agreement with the regulated $R^{2}$ of 0.9838 (the difference is lower than 0.2. Adeq precision evaluates the signal to noise ratio. A ratio higher than 4 is favourable. The ratio of 40.272 demonstrates a sufficient signal. This model possesses a great potential to navigate the design space. According to Response 2, the F-value of 75.20 proves the insignificance of the model. There is only a $0.01 \%$ chance that an F-value at this quantity might happen because of noise. P-values less than 0.05 illustrate the significance of model terms. In this case, B, C, D, E, F, AB, AC, AD, BD, BE, BG, CD, DG, EG, $\mathrm{A}^{2}, \mathrm{C}^{2}, \mathrm{D}^{2}, \mathrm{~F}^{2}, \mathrm{G}^{2}$ are significant model terms. Values higher than 0.1 , illustrate that the insignificance of the model. If there are numerous insignificant model terms, then the model reduction can boost the model's performance. F-value of 1.99 corroborates that the Lack of Fit is not considered as significant related to the pure error ${ }^{44}$. There is a $22.92 \%$ chance that a Lack of Fit F-value at this quantity might take place because of noise. Insignificant lack of fit is desirable. The predicted 


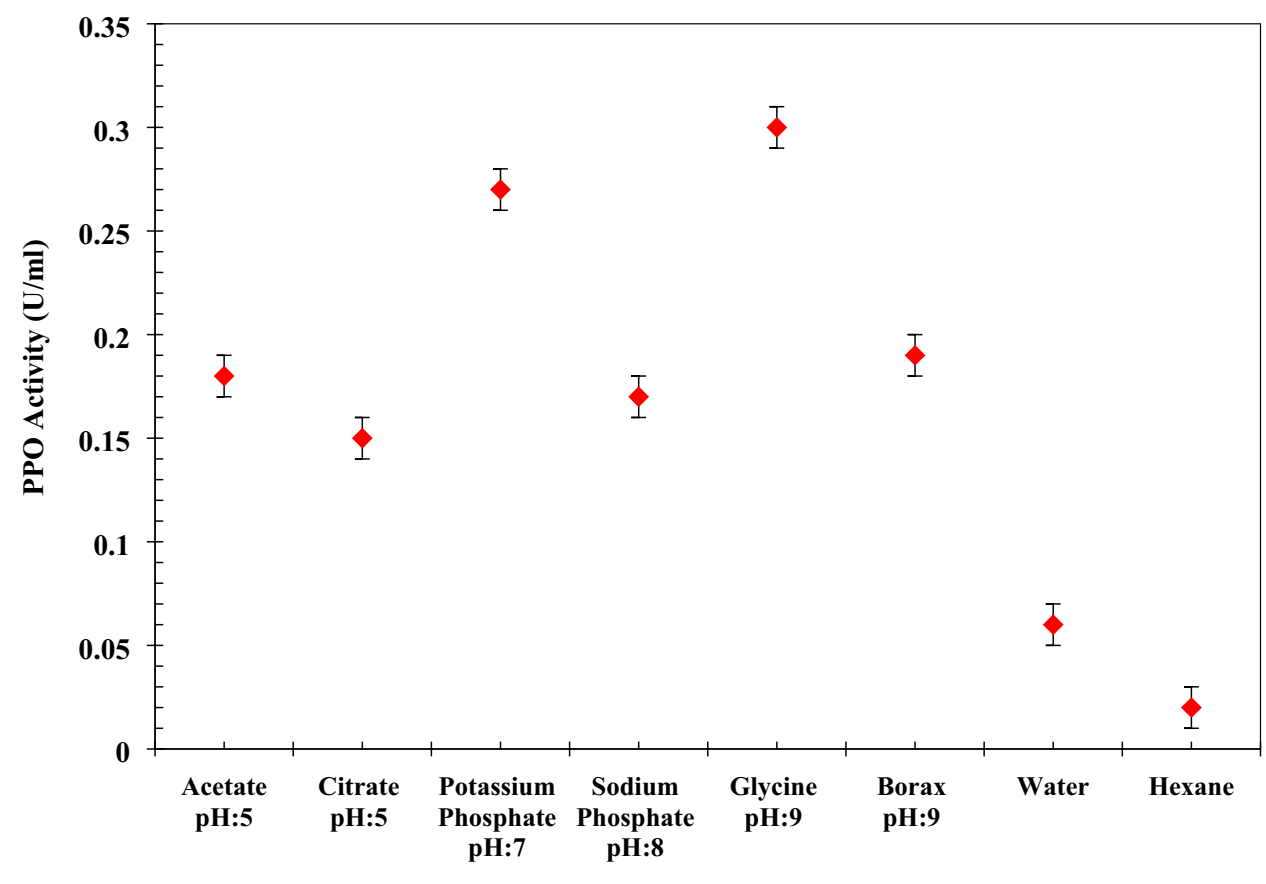

Type of Buffer Solvent

(A)

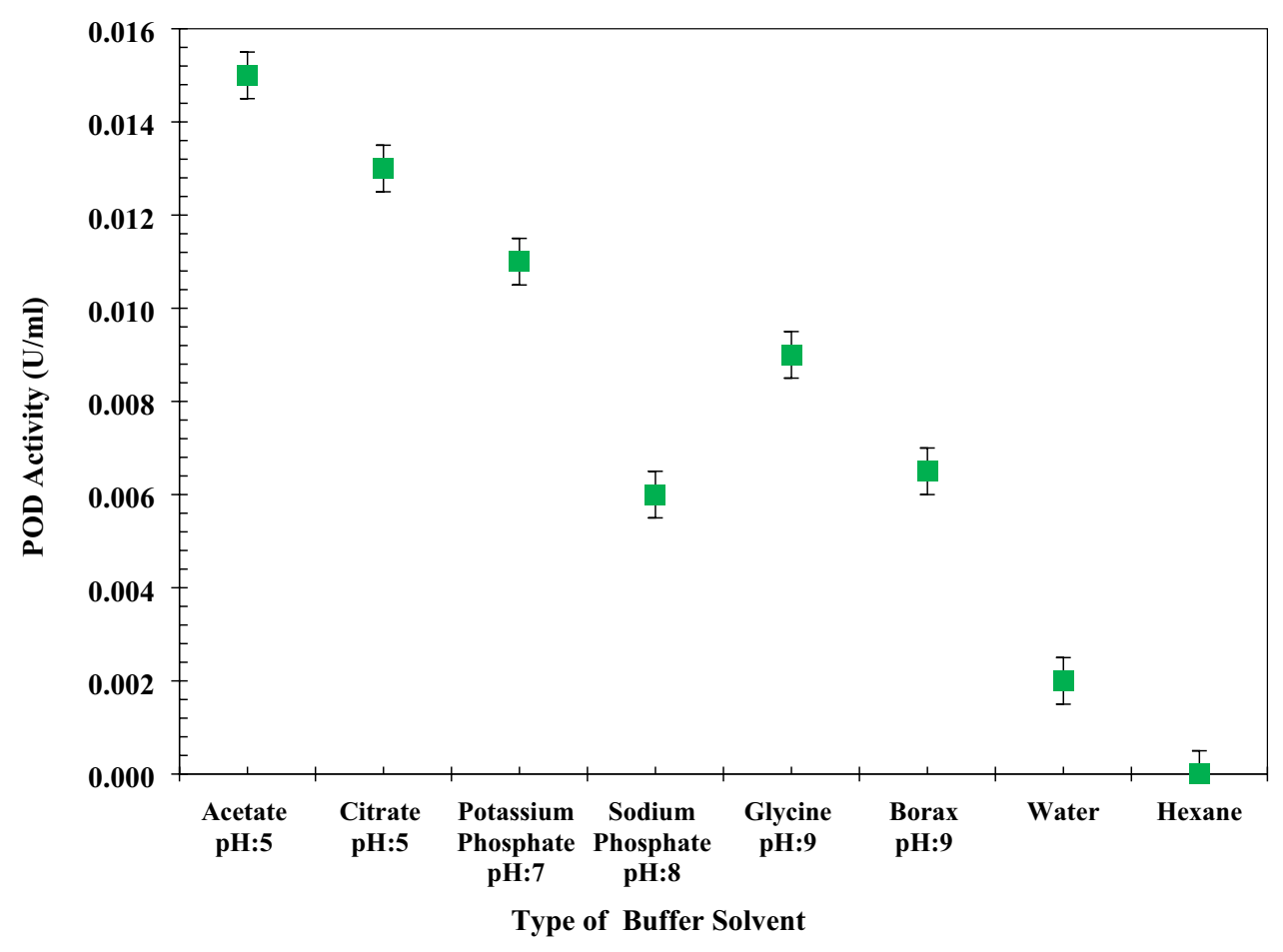

(B)

Figure 1. Influence of buffer solvent type on (A) PPO activity (B) POD activity.

$\mathrm{R}^{2}$ of 0.9574 is in acceptable accordance with the regulated $\mathrm{R}^{2}$ of 0.9839 (the difference is lower than 0.2). Adeq precision evaluates the signal to noise ratio. A ratio higher than 4 is favourable. The ratio of 40.783 illustrates a sufficient signal. This model is able to be applied to navigate the design space. As shown in Figs. 2 and 3, the results of this experiment are very complex and well illustrated by 7 factors affecting PPO and POD activities. 


\begin{tabular}{|c|c|c|c|c|c|c|c|c|c|}
\hline Run & $\mathrm{T}\left({ }^{\circ} \mathrm{C}\right)$ & $\mathrm{pH}$ & $L / S$ & $\mathbf{t}(\min )$ & Buff. Conc. (M) & PVP (\%) & Tween 80 (\%) & Response 1 & Response 2 \\
\hline & $\mathrm{X} 1$ & $\mathrm{X} 2$ & $\mathrm{X} 3$ & $\mathrm{X} 4$ & $\mathrm{X} 5$ & $\mathrm{X} 6$ & $\mathrm{X} 7$ & PPO activity $(\mathrm{U} / \mathrm{ml})$ & POD activity $(\mathrm{U} / \mathrm{ml})$ \\
\hline 1 & 0 & 0 & -1 & -1 & 0 & 0 & 1 & 0.205 & 0.012057 \\
\hline 2 & 0 & 0 & 0 & 0 & 0 & 0 & 0 & 0.296 & 0.017416 \\
\hline 3 & 0 & 0 & 0 & -1 & 1 & 1 & 0 & 0.323 & 0.018986 \\
\hline 4 & -1 & 0 & 0 & 0 & 0 & -1 & 1 & 0.311 & 0.018278 \\
\hline 5 & 1 & 0 & 0 & 0 & 0 & -1 & 1 & 0.310 & 0.018239 \\
\hline 6 & 0 & 0 & 0 & -1 & -1 & -1 & 0 & 0.278 & 0.016344 \\
\hline 7 & 0 & 0 & -1 & 1 & 0 & 0 & -1 & 0.162 & 0.009531 \\
\hline 8 & -1 & 0 & 0 & 0 & 0 & 1 & 1 & 0.420 & \begin{tabular}{|l|l|}
0.024689 \\
\end{tabular} \\
\hline 9 & 0 & 0 & 0 & 0 & 0 & 0 & 0 & 0.319 & 0.018756 \\
\hline 10 & 0 & 1 & 1 & 0 & 0 & 1 & 0 & 0.273 & 0.016077 \\
\hline 11 & 1 & 1 & 0 & 1 & 0 & 0 & 0 & 0.217 & \begin{tabular}{|l|l|}
0.012766 \\
\end{tabular} \\
\hline 12 & 0 & -1 & 0 & 0 & 1 & 0 & -1 & 0.287 & 0.016861 \\
\hline 13 & -1 & 0 & 1 & 0 & 1 & 0 & 0 & 0.244 & 0.014354 \\
\hline 14 & 1 & -1 & 0 & -1 & 0 & 0 & 0 & 0.392 & 0.023062 \\
\hline 15 & 0 & 1 & 0 & 0 & -1 & 0 & 1 & 0.236 & 0.013856 \\
\hline 16 & 0 & 0 & 0 & -1 & 1 & -1 & 0 & 0.268 & 0.015751 \\
\hline 17 & 0 & 0 & 0 & 1 & 1 & -1 & 0 & 0.278 & \begin{tabular}{|l|l|}
0.016344 \\
\end{tabular} \\
\hline 18 & 0 & -1 & 1 & 0 & 0 & -1 & 0 & 0.248 & 0.014584 \\
\hline 19 & 0 & 0 & 0 & 1 & -1 & -1 & 0 & 0.276 & 0.016249 \\
\hline 20 & 0 & 0 & -1 & -1 & 0 & 0 & -1 & 0.286 & 0.016823 \\
\hline 21 & -1 & 0 & 0 & 0 & 0 & 1 & -1 & 0.410 & 0.024096 \\
\hline 22 & -1 & 0 & -1 & 0 & -1 & 0 & 0 & 0.231 & \begin{tabular}{|l|l|}
0.013569 \\
\end{tabular} \\
\hline 23 & 0 & -1 & 1 & 0 & 0 & 1 & 0 & 0.326 & 0.019158 \\
\hline 24 & 0 & 0 & 0 & -1 & -1 & 1 & 0 & 0.369 & 0.021684 \\
\hline 25 & 0 & 0 & 1 & -1 & 0 & 0 & -1 & 0.250 & \begin{tabular}{|l|l|}
0.014718 \\
\end{tabular} \\
\hline 26 & 1 & -1 & 0 & 1 & 0 & 0 & 0 & 0.334 & 0.019636 \\
\hline 27 & 0 & -1 & 0 & 0 & -1 & 0 & 0 & 0.365 & \begin{tabular}{|l|l|}
0.025493 \\
\end{tabular} \\
\hline 28 & 0 & 1 & 0 & 0 & 1 & 0 & -1 & 0.292 & 0.017167 \\
\hline 29 & 0 & 0 & 0 & 1 & -1 & 1 & 0 & 0.376 & 0.022124 \\
\hline 30 & 0 & 1 & 0 & 0 & -1 & 0 & -1 & 0.340 & \begin{tabular}{|l|}
0.019981 \\
\end{tabular} \\
\hline 31 & 0 & -1 & -1 & 0 & 0 & -1 & 0 & 0.195 & 0.011445 \\
\hline 32 & 0 & -1 & 0 & 0 & -1 & 0 & 1 & 0.360 & \begin{tabular}{|l|l|}
0.021187 \\
\end{tabular} \\
\hline 33 & 0 & 0 & 1 & 1 & 0 & 0 & -1 & 0.242 & 0.014258 \\
\hline 34 & 0 & 0 & 0 & 0 & 0 & 0 & 0 & 0.303 & \begin{tabular}{|l|l|}
0.017837 \\
\end{tabular} \\
\hline 35 & -1 & 0 & -1 & 0 & 1 & 0 & 0 & 0.228 & 0.013416 \\
\hline 36 & -1 & 0 & 1 & 0 & -1 & 0 & 0 & 0.238 & 0.014010 \\
\hline 37 & -1 & 1 & 0 & -1 & 0 & 0 & 0 & 0.270 & \begin{tabular}{|l|l|}
0.015885 \\
\end{tabular} \\
\hline 38 & -1 & 0 & 0 & 0 & 0 & -1 & -1 & 0.306 & \begin{tabular}{|l|l|}
0.017990 \\
\end{tabular} \\
\hline 39 & 0 & 1 & -1 & 0 & 0 & 1 & 0 & 0.245 & 0.014431 \\
\hline 40 & 1 & 0 & 1 & 0 & 1 & 0 & 0 & 0.256 & 0.015081 \\
\hline 41 & 0 & -1 & -1 & 0 & 0 & 1 & 0 & 0.292 & 0.017148 \\
\hline 42 & 1 & 0 & -1 & 0 & -1 & 0 & 0 & 0.214 & 0.012612 \\
\hline 43 & 0 & 0 & 0 & 0 & 0 & 0 & 0 & 0.299 & \begin{tabular}{|l|}
0.017608 \\
\end{tabular} \\
\hline 44 & -1 & -1 & 0 & 1 & 0 & 0 & 0 & 0.394 & \begin{tabular}{|l|l|}
0.023158 \\
\end{tabular} \\
\hline 45 & 1 & 1 & 0 & -1 & 0 & 0 & 0 & 0.338 & \begin{tabular}{|l|}
0.019904 \\
\end{tabular} \\
\hline 46 & 0 & 0 & 1 & -1 & 0 & 0 & 1 & 0.177 & \begin{tabular}{|l|l|}
0.010392 \\
\end{tabular} \\
\hline 47 & 1 & 0 & 0 & 0 & 0 & -1 & -1 & 0.294 & \begin{tabular}{|l|l|}
0.017301 \\
\end{tabular} \\
\hline 48 & -1 & -1 & 0 & -1 & 0 & 0 & 0 & 0.250 & \begin{tabular}{|l|l|}
0.014718 \\
\end{tabular} \\
\hline 49 & 0 & 0 & 0 & 0 & 0 & 0 & 0 & 0.304 & 0.017876 \\
\hline 50 & 0 & 1 & 1 & 0 & 0 & -1 & 0 & 0.172 & 0.010144 \\
\hline 51 & 0 & 0 & -1 & 1 & 0 & 0 & 1 & 0.235 & \begin{tabular}{|l|l|}
0.013837 \\
\end{tabular} \\
\hline 52 & 0 & 0 & 0 & 0 & 0 & 0 & 0 & 0.307 & 0.018086 \\
\hline 53 & 0 & 1 & 0 & 0 & 1 & 0 & 1 & 0.306 & \begin{tabular}{|l|l|}
0.017971 \\
\end{tabular} \\
\hline 54 & 1 & 0 & 1 & 0 & -1 & 0 & 0 & 0.291 & \begin{tabular}{|l|}
0.017091 \\
\end{tabular} \\
\hline 55 & 1 & 0 & 0 & 0 & 0 & 1 & -1 & 0.411 & 0.024172 \\
\hline
\end{tabular}




\begin{tabular}{|l|c|r|r|l|l|l|l|l|l|}
\hline Run & $\mathbf{T}\left({ }^{\circ} \mathbf{C}\right)$ & $\mathbf{p H}$ & $\mathbf{L} / \mathbf{S}$ & $\mathbf{t}(\mathbf{m i n})$ & Buff. Conc. (M) & $\mathbf{P V P}(\%)$ & Tween 80 (\%) & Response 1 & Response 2 \\
\hline & $\mathbf{X 1}$ & $\mathbf{X 2}$ & $\mathbf{X 3}$ & $\mathbf{X} 4$ & $\mathbf{X 5}$ & $\mathbf{X 6}$ & $\mathbf{X 7}$ & $\mathbf{P P O}$ activity (U/ml) & POD activity (U/ml) \\
\hline 56 & 0 & 0 & 0 & 1 & 1 & 1 & 0 & 0.380 & 0.022354 \\
\hline 57 & 0 & 1 & -1 & 0 & 0 & -1 & 0 & 0.157 & 0.009244 \\
\hline 58 & 1 & 0 & 0 & 0 & 0 & 1 & 1 & 0.403 & 0.023732 \\
\hline 59 & 1 & 0 & -1 & 0 & 1 & 0 & 0 & 0.204 & 0.012000 \\
\hline 60 & 0 & 0 & 1 & 1 & 0 & 0 & 1 & 0.328 & 0.019311 \\
\hline 61 & 0 & -1 & 0 & 0 & 1 & 0 & 1 & 0.388 & 0.022813 \\
\hline 62 & -1 & 1 & 0 & 1 & 0 & 0 & 0 & 0.340 & 0.020000 \\
\hline
\end{tabular}

Table 1. The detailed specifications of the experiments and PPO/POD activity design based on the BoxBehnken method. Bold values indicate the maximum value.

Figures 2 and 3 illustrate the predicted values versus actual values plot for PPO/POD biocatalysts activities. The results indicated an excellent agreement between the model predictions and actual experimental values for both biocatalysts. Therefore, the developed model is confirmed to be an efficacious platform to bridge the correlation between process parameters to the PPO biocatalyst activity. In the continuation of Figs. 2 and 3, all the contours about the relationship of seven factors against each other and ultimately in relation to the activity of the biocatalyst are depicted. These contours appropriately determine the impact of each factor on biocatalyst activity. The impact of temperature on the activity of both PPO and POD biocatalysts was studied at 3 levels $\left(25^{\circ} \mathrm{C}, 50^{\circ} \mathrm{C}\right.$ and $75^{\circ} \mathrm{C}$ ). It was perceived that both PPO biocatalyst reaches to its maximum activity at $25^{\circ} \mathrm{C}$, while the maximum activity of occurs at $50^{\circ} \mathrm{C}$. As seen in Table 2, the influence of temperature on the extraction and activity of PPO and POD biocatalysts was achieved 55.67 and $22.70 \%$, respectively. Ref. ${ }^{45}$ offered the best temperature of $20^{\circ} \mathrm{C}$ for extraction of PPO from lychee ${ }^{45}$. In another study, Yue-Ming et al. reported that the optimum temperature for the PPO activity is about $65^{\circ} \mathrm{C}^{46}$. It is able to be found out from the Table 2 that the impact of $\mathrm{pH}$ on the extraction and activity of PPO and POD biocatalysts was 24.07 and $47.89 \%$, respectively. The results prove that the increment of $\mathrm{pH}$ eventuates in decreasing the activity of PPO and increasing the PPO extraction. However, POD response to $\mathrm{pH}$ alteration isn't desirable, which results in decreasing the POD separation by rising $\mathrm{pH}$ of medium. Rudra Shalini understood that the $\mathrm{pH}$ values of 7.6 and 6.4 are optimum for PPO and POD activity ${ }^{47}$. Also, the highest amount of PPO activity was in the range of 5-7.5 for the source of bean seeds ${ }^{48}$. It is profoundly believed that tea leaves are considered as an appropriate source for biocatalyst utilization in fundamental media. Biocatalysts (Enzymes) are known as amphoteric molecules, which possess various basic/acidic groups. Alteration of the electric charge of groups is occurred by changing the $\mathrm{pH}$ value. It is obvious that changing in the electric charge of groups eventuates in altering the biocatalyst's net charge and its surface charge and subsequently influences the active part of biocatalyst. Overall, the amount of biocatalysts activity around the isoelectric point is maximum and declines gradually when the $\mathrm{pH}$ of solution is far from the isoelectric point. The impact of the ratio of buffer to mass of tea was done in three ratios $(3,5$, and 7$)$. This parameter varies the amount of PPO/POD activity and extraction by about $0.01 \%$. It would be clear that the effect of buffer-to-mass of tea leaves ratio (L/S) on the POD activity is ignorable. By enhancing the L/S ratio, the activity of PPO biocatalyst increased at first and after that declined. Enhancement of the L/S ratio to an optimum value improves the activity of the biocatalyst. Additionally, increment of the L/S ratio significantly improves mass transfer because of enhancing driving force between two phases ${ }^{49}$. Therefore, increment of L/S ratio may result in the dilution of solution and consequently declining the concentration and activity of biocatalyst in the system. Moreover, the impact of contact between tea leaves and buffer for PPO and POD biocatalysts was achieved 10.50 and 22.17\%, respectively. Also, buffer concentration was evaluated in the range of $0.05-0.2 \mathrm{M}$ and it was resulted that it does not have significant influence on the biocatalysts activity. Tea leaves consist of 20-30\% various natural polyphenols. Some investigators recommended the addition of PVP into the system to avoid oxidation of these components during extraction process. PVP was applied with the aim of separating polyphenols from biocatalyst solution applying formation of hydrogen bond ${ }^{17,50}$. It can be denoted that the concentration of PVP enhanced from 0 to $6 \%$. Moreover, it is perceived that increase in the PVP concentration improves the activity of PPO/POD biocatalysts. According to ANOVA analysis, the relative impact of PVP addition was achieved 9.08 and $7.13 \%$ for PPO and PO, respectively. The exact location of PPO and POD biocatalysts is inside the chloroplast cell. Hence, it is mandatory to apply a surfactant to enhance the activity of enzyme and the efficiency of extraction. By conducting an experimental investigation, Mayer reached to this result that addition of 105 and 15\% Triton X-100 eventuated in increasing the extraction efficiency of PPO biocatalyst from apple and tobacco by about 44 and $77 \%$, respectively ${ }^{51}$. In the recent investigation, Tween 80 concentration is applied in the range of $0-20 \%$. According to the obtained data from optimization analysis, it is concluded that the addition of Tween 80 possesses substantial influence on the activity amount PPO and POD. The value of effect was computed 22 and $19 \%$ for PPO/POD activity and extraction, respectively. The addition of $5 \%$ is considered as the optimum concentration due to the fact that $20 \%$ Tween 80 results in producing great amount of in the system ${ }^{17}$.

Moreover, Figs. 2 and 3 demonstrate the relationship of seven factors influencing the activity of PPO and POD biocatalysts. The only difference between these two figures is that the connection is displayed in 3D. Due to the complexity of the experiments, this difference helps to have a better understanding of the relationship between the parameters affecting the activity of the two enzymes. 


\begin{tabular}{|c|c|c|c|c|c|c|}
\hline Source & Sum of squares & Df & Mean square & F value & P value & \\
\hline \multicolumn{7}{|c|}{ Response 1: PPO Activity (U/ml) } \\
\hline Model & 0.2614 & 35 & 0.0075 & 106.73 & $<0.0001$ & Significant \\
\hline A-Temperature & 0.0000 & 1 & 0.0000 & 35.46 & $<0.0001$ & Significant \\
\hline B-pH & 0.0172 & 1 & 0.0172 & 246.36 & $<0.0001$ & Significant \\
\hline C-L/S & 0.0064 & 1 & 0.0064 & 91.52 & $<0.0001$ & Significant \\
\hline D-t (min) & 0.0010 & 1 & 0.0010 & 14.70 & 0.0007 & Significant \\
\hline E-Buffer. Conc. (M) & 0.0006 & 1 & 0.0006 & 8.68 & 0.0067 & Significant \\
\hline F-PVP (\%) & 0.0536 & 1 & 0.0536 & 766.42 & $<0.0001$ & Significant \\
\hline G-Tween-80 (\%) & 0.0000 & 1 & 0.0000 & 0.6687 & $<0.0001$ & Significant \\
\hline $\mathrm{AB}$ & 0.0023 & 1 & 0.0023 & 33.36 & $<0.0001$ & Significant \\
\hline $\mathrm{AC}$ & 0.0014 & 1 & 0.0014 & 19.73 & 0.0001 & Significant \\
\hline $\mathrm{AD}$ & 0.0193 & 1 & 0.0193 & 275.94 & $<0.0001$ & Significant \\
\hline $\mathrm{AE}$ & 0.0003 & 1 & 0.0003 & 4.09 & 0.0536 & Not significant \\
\hline $\mathrm{AF}$ & $8.469 \mathrm{E}-07$ & 1 & $8.469 \mathrm{E}-07$ & 0.0121 & 0.9132 & Not significant \\
\hline AG & $5.293 \mathrm{E}-06$ & 1 & $5.293 \mathrm{E}-06$ & 0.0756 & 0.7855 & Not significant \\
\hline $\mathrm{BC}$ & 0.0002 & 1 & 0.0002 & 3.50 & 0.0728 & Not significant \\
\hline $\mathrm{BD}$ & 0.0023 & 1 & 0.0023 & 33.36 & $<0.0001$ & Significant \\
\hline $\mathrm{BE}$ & 0.0007 & 1 & 0.0007 & 9.57 & 0.0047 & Significant \\
\hline $\mathrm{BF}$ & 0.0000 & 1 & 0.0000 & 0.3661 & 0.5504 & Not significant \\
\hline BG & 0.0043 & 1 & 0.0043 & 62.09 & $<0.0001$ & Significant \\
\hline $\mathrm{CD}$ & 0.0071 & 1 & 0.0071 & 100.77 & $<0.0001$ & Significant \\
\hline $\mathrm{CE}$ & 0.0000 & 1 & 0.0000 & 0.4177 & 0.5237 & Not significant \\
\hline $\mathrm{CF}$ & $5.293 \mathrm{E}-06$ & 1 & $5.293 \mathrm{E}-06$ & 0.0756 & 0.7855 & Not significant \\
\hline CG & 0.0001 & 1 & 0.0001 & 0.7269 & 0.4017 & Not significant \\
\hline $\mathrm{DE}$ & 0.0005 & 1 & 0.0005 & 6.75 & 0.0152 & Significant \\
\hline $\mathrm{DF}$ & 0.0004 & 1 & 0.0004 & 5.66 & 0.0250 & Significant \\
\hline DG & 0.0123 & 1 & 0.0123 & 175.73 & $<0.0001$ & Significant \\
\hline $\mathrm{EF}$ & 0.0001 & 1 & 0.0001 & 2.01 & 0.1685 & Not significant \\
\hline EG & 0.0063 & 1 & 0.0063 & 89.77 & $<0.0001$ & Significant \\
\hline FG & 0.0000 & 1 & 0.0000 & 0.5930 & 0.4482 & Not significant \\
\hline $\mathrm{A}^{2}$ & 0.0040 & 1 & 0.0040 & 56.50 & $<0.0001$ & Significant \\
\hline $\mathrm{B}^{2}$ & 0.0000 & 1 & 0.0000 & 0.2030 & 0.6560 & Not significant \\
\hline $\mathrm{C}^{2}$ & 0.0936 & 1 & 0.0936 & 1337.38 & $<0.0001$ & Significant \\
\hline $\mathrm{D}^{2}$ & 0.0002 & 1 & 0.0002 & 3.08 & 0.0911 & Not significant \\
\hline $\mathrm{E}^{2}$ & $1.899 \mathrm{E}-06$ & 1 & $1.899 \mathrm{E}-06$ & 0.0271 & 0.8704 & Not significant \\
\hline $\mathrm{F}^{2}$ & 0.0044 & 1 & 0.0044 & 62.28 & $<0.0001$ & Significant \\
\hline $\mathrm{G}^{2}$ & 0.0045 & 1 & 0.0045 & 63.70 & $<0.0001$ & Significant \\
\hline Residual & 0.0018 & 26 & 0.0001 & & & \\
\hline Lack of Fit & 0.0015 & 21 & 0.0001 & 1.14 & 0.4858 & not significant \\
\hline Pure Error & 0.0003 & 5 & 0.0001 & & & \\
\hline Cor Total & 0.2632 & 61 & $\mathrm{R}^{2}$ & & & 0.9931 \\
\hline Std. Dev & 0.0084 & & Adjusted $\mathrm{R}^{2}$ & & & 0.9838 \\
\hline Mean & 0.2911 & & Predicted $\mathrm{R}^{2}$ & & & 0.9576 \\
\hline C.V. $\%$ & 2.87 & & Adeq Precision & & & 40.2724 \\
\hline \multicolumn{7}{|c|}{ Response 2: POD Activity $(\mathrm{U} / \mathrm{ml})$} \\
\hline Model & $1.420 \mathrm{E}-06$ & 35 & $4.057 \mathrm{E}-08$ & 75.20 & $<0.0001$ & Significant \\
\hline A-Temperature & $8.234 \mathrm{E}-11$ & 1 & $8.234 \mathrm{E}-11$ & 15.26 & $<0.0001$ & Significant \\
\hline B-pH & $1.057 \mathrm{E}-07$ & 1 & $1.057 \mathrm{E}-07$ & 195.88 & $<0.0001$ & Significant \\
\hline C-L/S & $3.911 \mathrm{E}-08$ & 1 & $3.911 \mathrm{E}-08$ & 72.50 & $<0.0001$ & Significant \\
\hline D-t (min) & $4.389 \mathrm{E}-09$ & 1 & $4.389 \mathrm{E}-09$ & 8.14 & 0.0084 & Significant \\
\hline E-Buffer. Conc. (M) & $6.298 \mathrm{E}-09$ & 1 & $6.298 \mathrm{E}-09$ & 11.67 & 0.0021 & Significant \\
\hline F-PVP (\%) & $2.652 \mathrm{E}-07$ & 1 & $2.652 \mathrm{E}-07$ & 491.60 & $<0.0001$ & Significant \\
\hline G-Tween-80 (\%) & $2.785 \mathrm{E}-10$ & 1 & $2.785 \mathrm{E}-10$ & 0.5163 & 0.4789 & Not significant \\
\hline $\mathrm{AB}$ & $1.271 \mathrm{E}-08$ & 1 & $1.271 \mathrm{E}-08$ & 23.56 & $<0.0001$ & Significant \\
\hline $\mathrm{AC}$ & $8.343 \mathrm{E}-09$ & 1 & $8.343 \mathrm{E}-09$ & 15.47 & 0.0006 & Significant \\
\hline $\mathrm{AD}$ & $9.261 \mathrm{E}-08$ & 1 & $9.261 \mathrm{E}-08$ & 171.68 & $<0.0001$ & Significant \\
\hline Continued & & & & & & \\
\hline
\end{tabular}




\begin{tabular}{|c|c|c|c|c|c|c|}
\hline Source & Sum of squares & Df & Mean square & F value & P value & \\
\hline $\mathrm{AE}$ & $1.646 \mathrm{E}-09$ & 1 & $1.646 \mathrm{E}-09$ & 3.05 & 0.0925 & Not significant \\
\hline $\mathrm{AF}$ & $1.097 \mathrm{E}-13$ & 1 & $1.097 \mathrm{E}-13$ & 0.0002 & 0.9887 & Not significant \\
\hline AG & $9.456 \mathrm{E}-12$ & 1 & $9.456 \mathrm{E}-12$ & 0.0175 & 0.8957 & Not significant \\
\hline $\mathrm{BC}$ & $1.252 \mathrm{E}-09$ & 1 & $1.252 \mathrm{E}-09$ & 2.32 & 0.1398 & Not significant \\
\hline $\mathrm{BD}$ & $1.267 \mathrm{E}-08$ & 1 & $1.267 \mathrm{E}-08$ & 23.49 & $<0.0001$ & Significant \\
\hline $\mathrm{BE}$ & $1.151 \mathrm{E}-08$ & 1 & $1.151 \mathrm{E}-08$ & 21.33 & $<0.0001$ & Significant \\
\hline $\mathrm{BF}$ & $8.905 \mathrm{E}-10$ & 1 & $8.905 \mathrm{E}-10$ & 1.65 & 0.2102 & Not significant \\
\hline BG & $9.584 \mathrm{E}-09$ & 1 & $9.584 \mathrm{E}-09$ & 17.77 & 0.0003 & Significant \\
\hline $\mathrm{CD}$ & $4.405 \mathrm{E}-08$ & 1 & $4.405 \mathrm{E}-08$ & 81.66 & $<0.0001$ & Significant \\
\hline $\mathrm{CE}$ & $1.170 \mathrm{E}-10$ & 1 & $1.170 \mathrm{E}-10$ & 0.2170 & 0.6452 & Not significant \\
\hline $\mathrm{CF}$ & $2.231 \mathrm{E}-10$ & 1 & $2.231 \mathrm{E}-10$ & 0.4136 & 0.5258 & Not significant \\
\hline CG & $6.890 \mathrm{E}-14$ & 1 & $6.890 \mathrm{E}-14$ & 0.0001 & 0.9911 & Not significant \\
\hline $\mathrm{DE}$ & $2.098 \mathrm{E}-09$ & 1 & $2.098 \mathrm{E}-09$ & 3.89 & 0.0594 & Not significant \\
\hline $\mathrm{DF}$ & $1.580 \mathrm{E}-09$ & 1 & $1.580 \mathrm{E}-09$ & 2.93 & 0.0989 & Not significant \\
\hline DG & $7.768 \mathrm{E}-08$ & 1 & $7.768 \mathrm{E}-08$ & 143.99 & $<0.0001$ & Significant \\
\hline EF & $5.662 \mathrm{E}-10$ & 1 & $5.662 \mathrm{E}-10$ & 1.05 & 0.3151 & Not significant \\
\hline EG & $4.801 \mathrm{E}-08$ & 1 & $4.801 \mathrm{E}-08$ & 88.99 & $<0.0001$ & Significant \\
\hline FG & $2.108 \mathrm{E}-10$ & 1 & $2.108 \mathrm{E}-10$ & 0.3907 & 0.5374 & Not significant \\
\hline $\mathrm{A}^{2}$ & $1.492 \mathrm{E}-08$ & 1 & $1.492 \mathrm{E}-08$ & 27.65 & $<0.0001$ & Significant \\
\hline $\mathrm{B}^{2}$ & $2.355 \mathrm{E}-12$ & 1 & $2.355 \mathrm{E}-12$ & 0.0044 & 0.9478 & Not significant \\
\hline $\mathrm{C}^{2}$ & $5.210 \mathrm{E}-07$ & 1 & $5.210 \mathrm{E}-07$ & 965.83 & $<0.0001$ & Significant \\
\hline $\mathrm{D}^{2}$ & $2.580 \mathrm{E}-09$ & 1 & $2.580 \mathrm{E}-09$ & 4.78 & 0.0380 & Significant \\
\hline $\mathrm{E}^{2}$ & $5.933 \mathrm{E}-10$ & 1 & $5.933 \mathrm{E}-10$ & 1.10 & 0.3039 & Not significant \\
\hline $\mathrm{F}^{2}$ & $1.490 \mathrm{E}-08$ & 1 & $1.490 \mathrm{E}-08$ & 27.62 & $<0.0001$ & Significant \\
\hline $\mathrm{G}^{2}$ & $2.364 \mathrm{E}-08$ & 1 & $2.364 \mathrm{E}-08$ & 43.83 & $<0.0001$ & Significant \\
\hline Residual & $1.403 \mathrm{E}-08$ & 26 & $5.395 \mathrm{E}-10$ & & & \\
\hline Lack of Fit & $1.253 \mathrm{E}-08$ & 21 & $5.965 \mathrm{E}-10$ & 1.99 & 0.2292 & Not Significant \\
\hline Pure Error & $1.499 \mathrm{E}-09$ & 5 & $2.999 \mathrm{E}-10$ & & & \\
\hline Cor Total & $1.434 \mathrm{E}-06$ & 61 & $\mathrm{R}^{2}$ & & & 0.9931 \\
\hline Std. Dev & 0.0000 & & Adjusted R ${ }^{2}$ & & & 0.9839 \\
\hline Mean & 0.0013 & & Predicted $\mathrm{R}^{2}$ & & & 0.9574 \\
\hline C.V. $\%$ & 1.46 & & Adeq Precision & & & 40.7835 \\
\hline
\end{tabular}

Table 2. Effect of disparate parameters on the PPO and POD activity (ANOVA).

RSM procedure is employed to achieve the optimum conditions for 8 parameters through a set of minimum number of experiments. The optimum operating conditions for extraction of PPO and POD biocatalysts applying the RSM technique are presented in Table 3 . The amount of response at optimum conditions is obtained $0.41 \mathrm{U} / \mathrm{mL}$ (experimental value $=0.42$ ) and $2.249 \mathrm{E}-06 \mathrm{U} / \mathrm{mL}$ (experimental value $=2.549 \mathrm{E}-06$ ) for PPO and POD, respectively. It is obvious from the table that RSM procedure can appropriately estimate the optimum conditions particularly for PPO.

Data fitting for biocatalyst activity. To develop an appropriate regression model for biocatalyst activity, Data Fit 9 software is aimed to be applied. A data fitting is performed for PPO and POD biocatalysts (Eq. 1 for PPO and Eq. 2 for POD) according to the second order equations. The results are presented as follows:

PPO Activity $(\mathrm{U} / \mathrm{ml})=+0.3048+[0.0010 * A]-[0.0268 * B]+[0.0163 * C]+[0.0065 * D]$

$-[0.0050 * E]+[0.0473 * F]+[0.0014 * G]-[0.0171 * A * B]+[0.0131 * A * C]-[0.0491 * A * D]$

$-[0.0060 * A * E]-[0.0003 * A * F]-[0.0008 * A * G]-[0.0055 * B]$

$-[0.0171 * B * D]+[0.0092 * B * E]+[0.0018 * B * F]-[0.0233 * B * G]+[0.0297 * C * D]-[0.0019 * C * E]$

$-[0.0008 * C F]+[0.0025 * C * G]+[0.0077 * D * E]+[0.0070 * D * F]+[0.0392 * D * G]$

$-[0.0042 * E * F]+[0.0280 * E * G]-[0.0023 * F G]+\left[0.0171 * A^{2}\right]-\left[0.0010 * B^{2}\right]-\left[0.0833 * C^{2}\right]-\left[0.0040 * D^{2}\right]$

$-\left[0.0004 * E^{2}\right]+\left[0.0180 * F^{2}\right]+\left[0.0182 * G^{2} * C\right]$ 

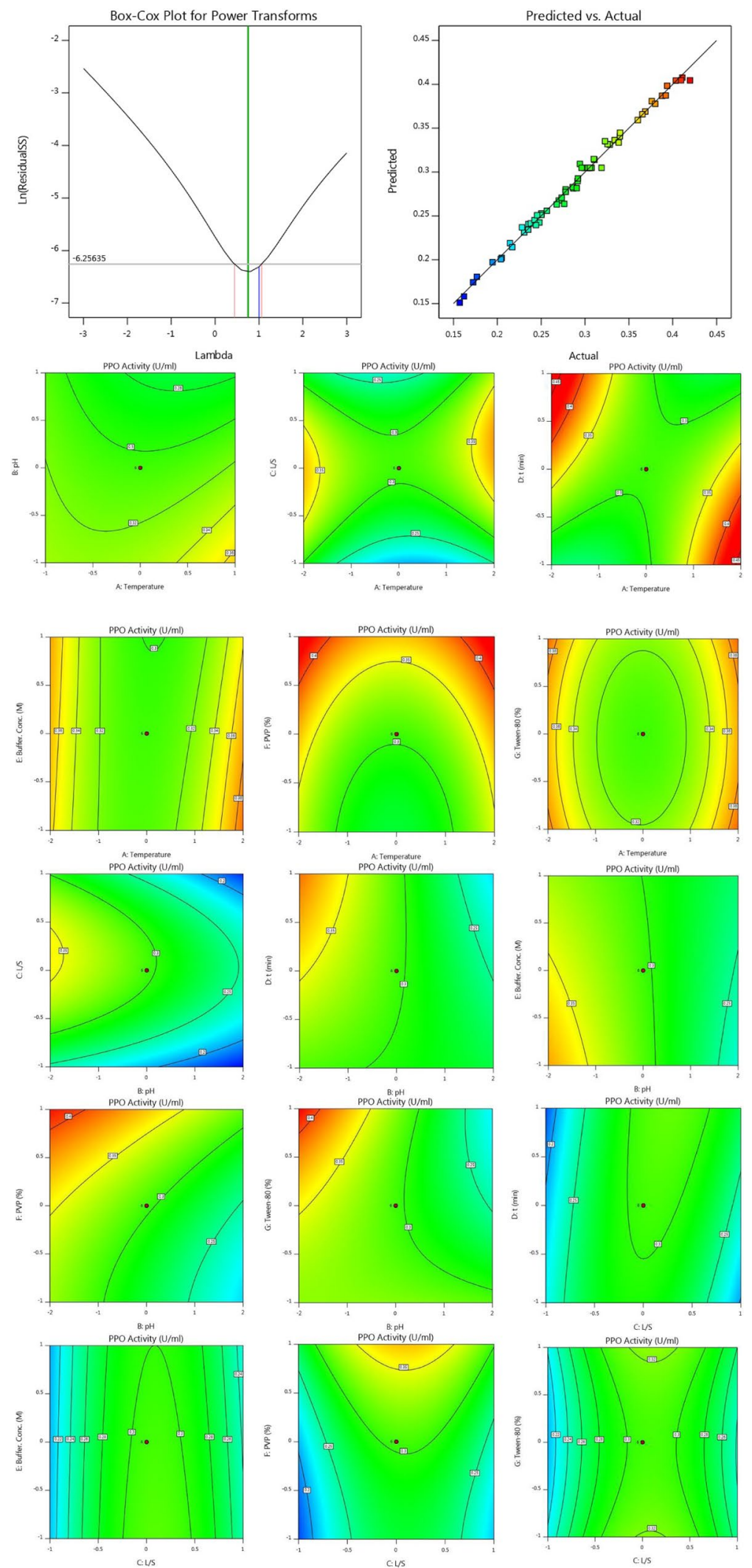

Figure 2. The plot of relationship between predicted and actual values of PPO enzyme activity and Contours of the effect of seven parameters on PPO enzyme activity and 3D response surface plots for the effect of seven parameters on PPO enzyme activity. 

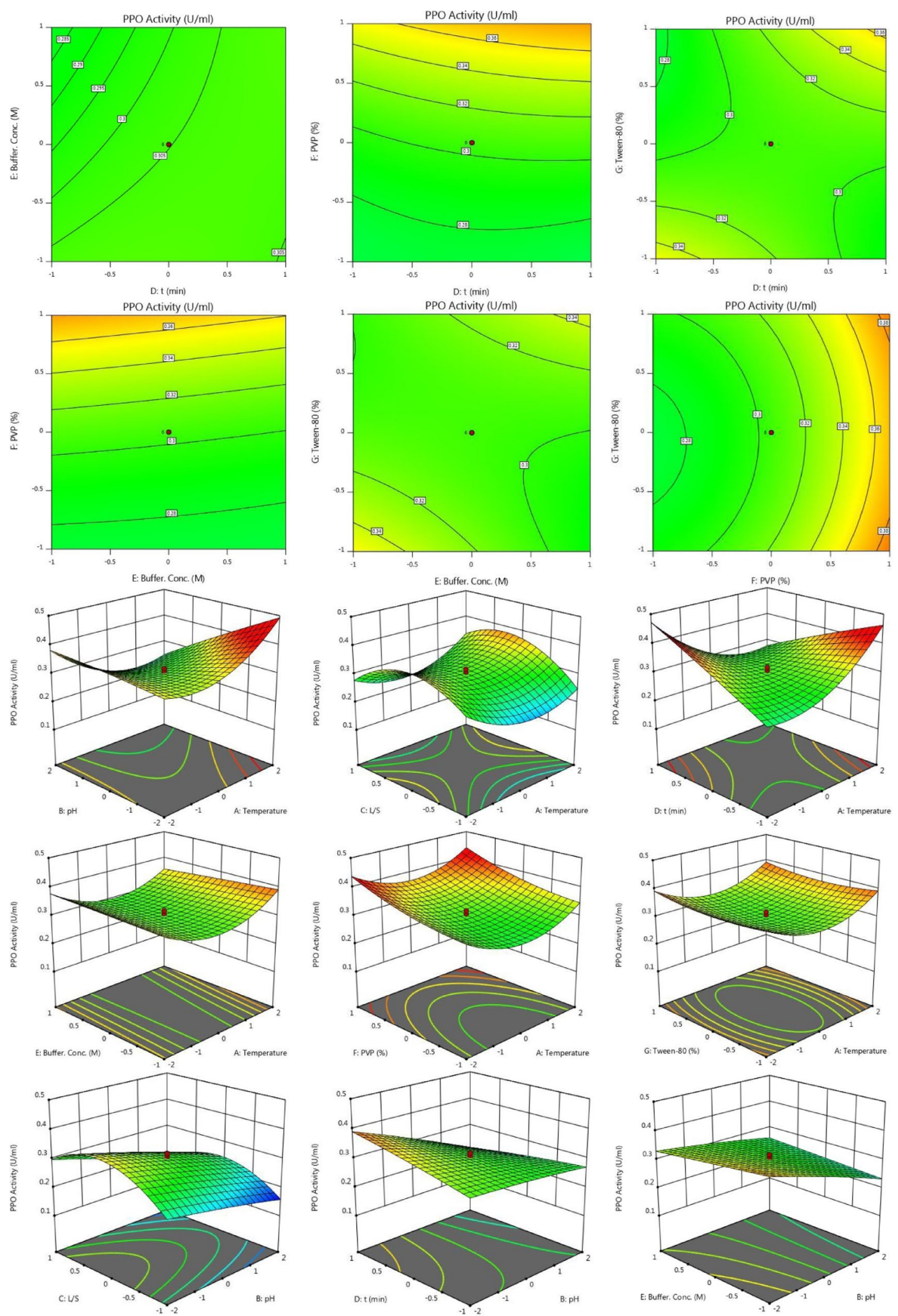

Figure 2. (continued) 

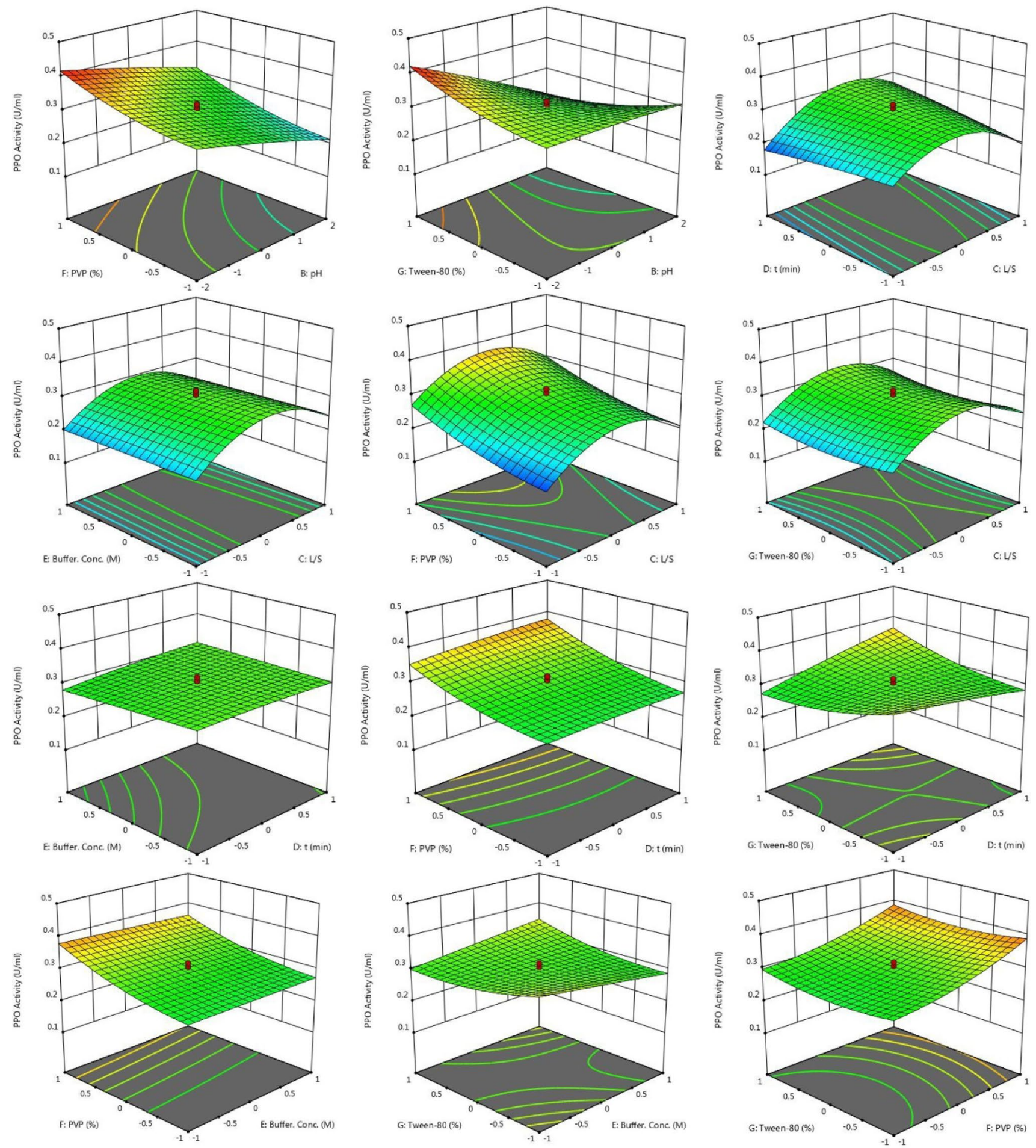

Figure 2. (continued) 

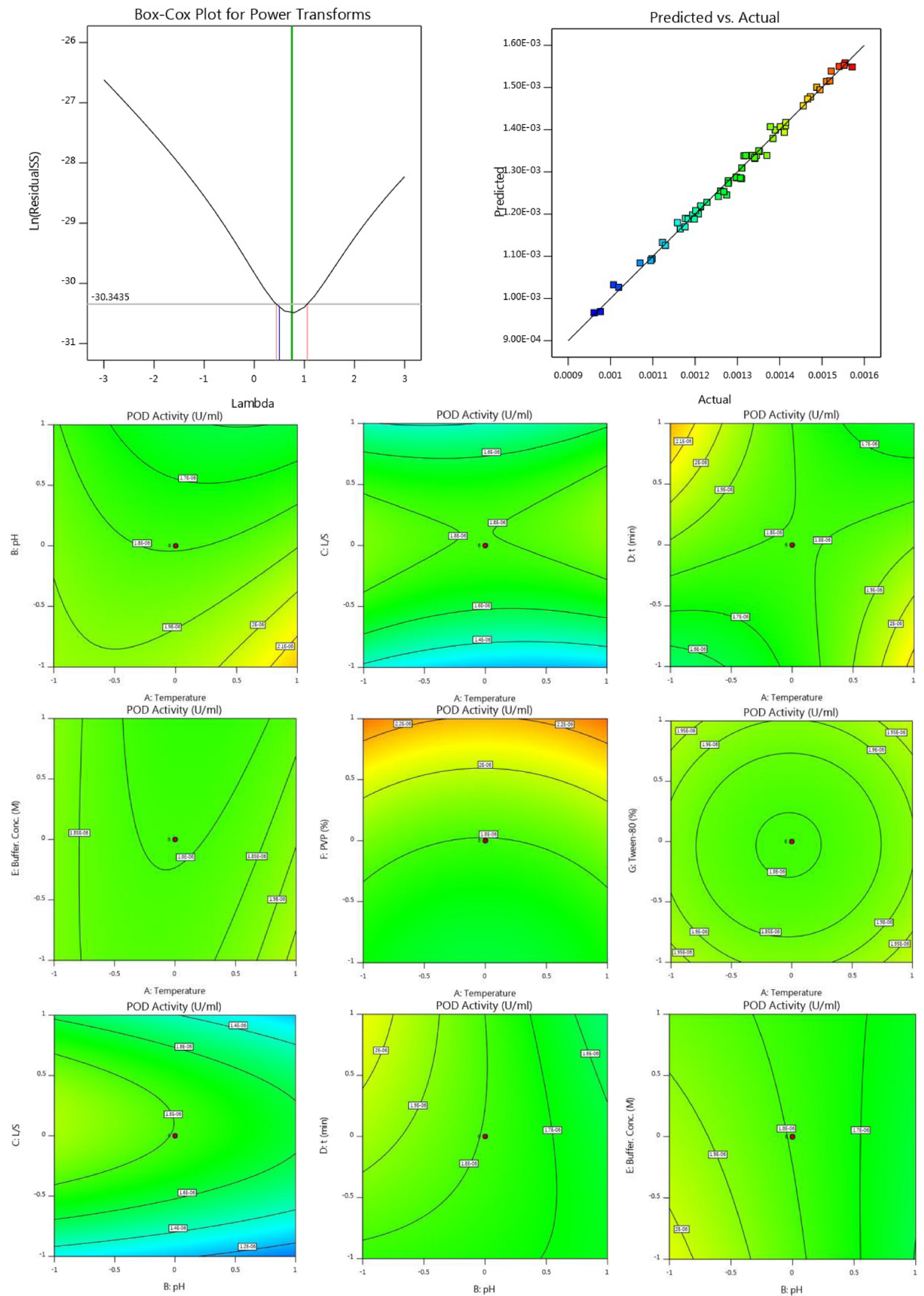

Figure 3. The plot of relationship between predicted and actual values of POD enzyme activity and Contours of the effect of seven parameters on POD enzyme activity and 3D response surface plots for the effect of seven parameters on POD enzyme activity. 

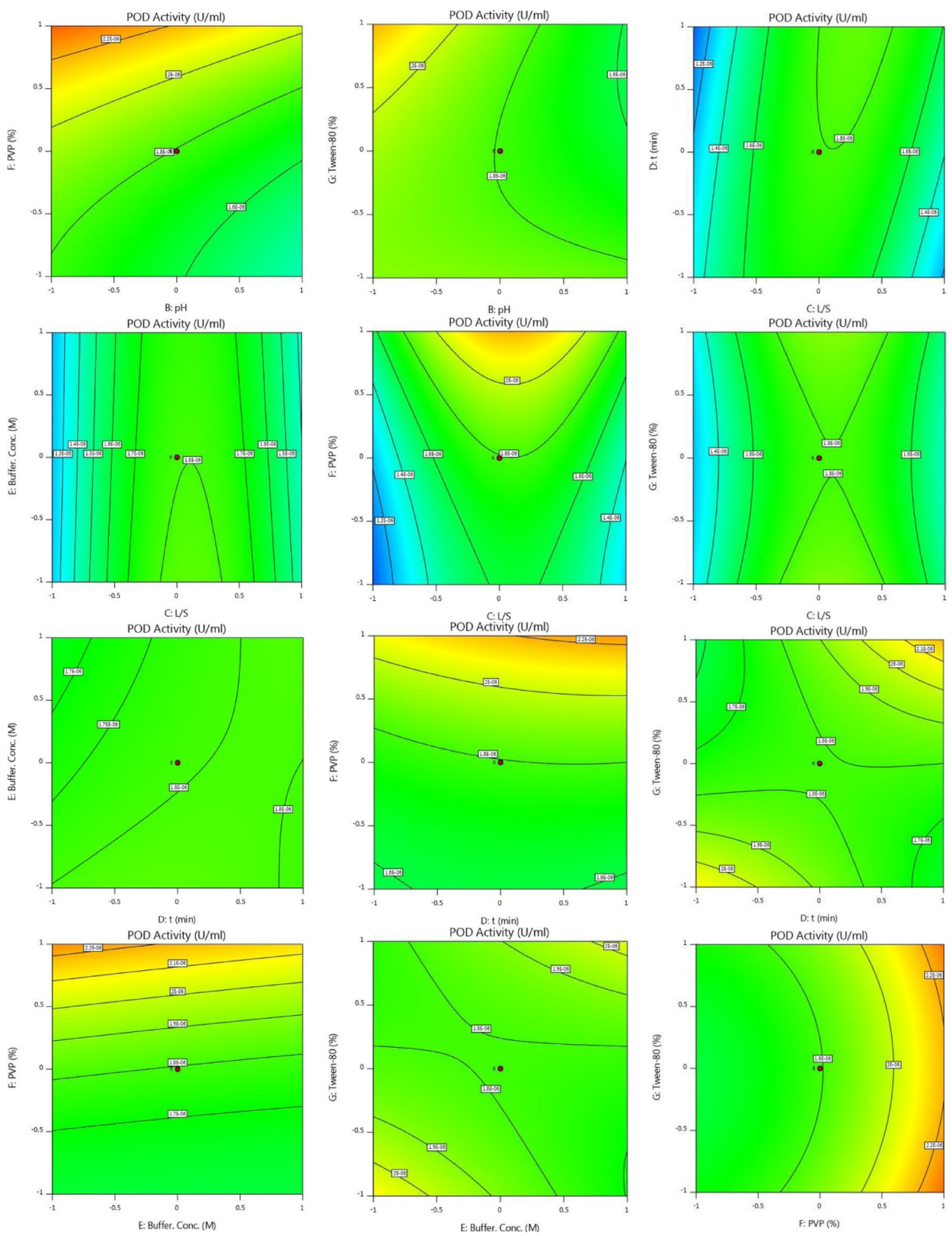

Figure 3. (continued) 

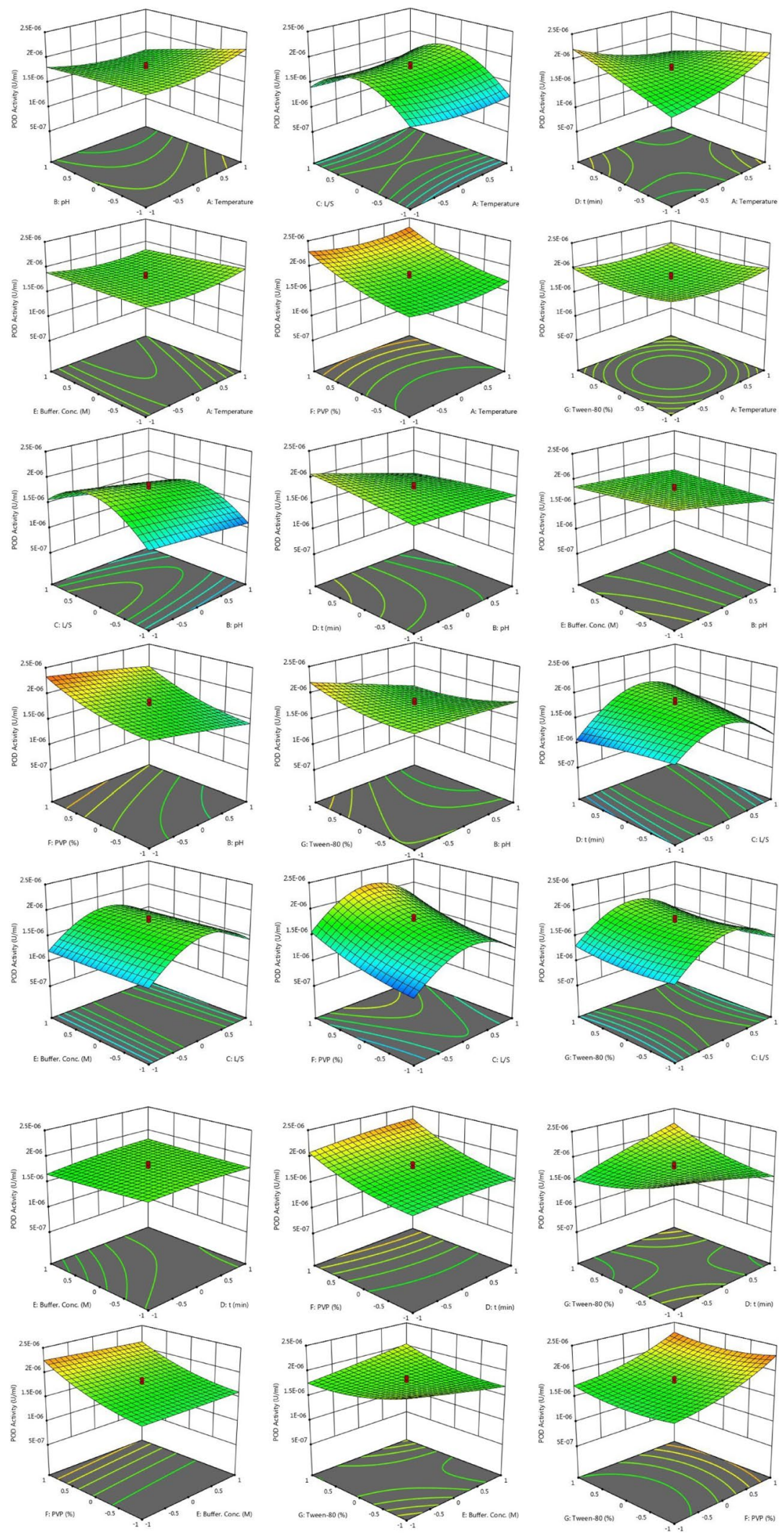

Figure 3. (continued) 


$$
\begin{aligned}
& \text { Sqrt }(\text { POD Activity }(\mathrm{U} / \mathrm{ml}))=+0.0013+[1.852 E-06 * A]-[0.0001 * B]+[0.00006 * C]+[0.00004 * D] \\
& -[0.000014 * E]+[0.0001 * F]-[3.406 E-06 * G]-[0.00004 * A * B]+[0.000032 * A * C]-[0.0001 * A * D] \\
& -[0.00001 * A * E]-[1.171 E-07 * A * F]-[1.087 E-06 * A * G]-[0.00001 * B * C] \\
& -[0.00004 * B * D]+[0.00003 * B * E]+[0.00001 * B * F]-[0.00003 * B * G]+[0.000074 * C * D] \\
& -[3.825 E-06 * C * E]-[5.281 E-06 * C * F]+[9.281 * E] \\
& -[08 * C * G]+[0.000016 * D * E]+[0.000014 * D * F]+[0.0001 * D * G]-[8.413 E-06 * E * F]+[0.0001 * E G] \\
& -[5.133 E-06 * F * G]+\left[0.000033 * A^{2}\right]+\left[4.176 E-07 * B^{2}\right]-\left[0.0002 * C^{2}\right]-\left[0.0000 * D^{2}\right] \\
& +\left[6.630 E-06 * E^{2}\right]+\left[0.000033 * F^{2}\right]+\left[0.000042 * G^{2}\right]
\end{aligned}
$$

In the case of actual factors, these equations are able to be applied to provide estimations. The computed amounts of activity for PPO/POD biocatalysts considering different operating conditions (62 experiments) applying Eqs. (1) and (2) are provided in Table S1 (Supplementary file). Coefficient of determination $\left(\mathrm{R}^{2}\right)$ was more than 95.76 and 95.74 for PPO and POD biocatalysts, respectively.

Protein content. In this section, the protein content for PPO and POD biocatalysts at the optimum operating conditions is aimed to be obtained. The protein amount for both abovementioned biocatalysts was achieved $0.26 \mathrm{mg}$ protein $/ \mathrm{mL}$. For this purpose, $10 \mathrm{~g}$ tea leaves was applied in $25 \mathrm{~mL}$ buffer. Hence, it is able to be concluded that there is $0.40 \mathrm{~g}$ tea leaves in each $\mathrm{mL}$ of buffer solution. According to this observation, $0.46 \mathrm{mg}$ protein is existed in $1 \mathrm{~g}$ tea leaves. Calculation of the specific activity is performed according to the protein content. The specific activities of both biocatalysts are computed 3.1 (U/mg protein) and 1.76 (U/g leaves) for PPO and 0.31 (U/mg protein) and 0.083 (U/g leaves) for POD, respectively.

Enzymes heat stability. Figure $4 \mathrm{~A}$ and B demonstrate the heat stability of PPO/POD biocatalysts as a function of time and temperature. It is clear from Fig. 4A that, the amount of PPO biocatalyst activity declines slowly until $15 \mathrm{~min}$ when the temperature is 40 and $60^{\circ} \mathrm{C}$, respectively. But, after $15 \mathrm{~min}$, the amount of PPO biocatalyst activity decreases substantially till end time which is half an hour. PPO activity is $10 \%$ when the temperature is $40{ }^{\circ} \mathrm{C}$ at $30 \mathrm{~min}$ and completely inactive at $45 \mathrm{~min}$ but it is also completely inactive at $30 \mathrm{~min}$ when temperature reaches $60{ }^{\circ} \mathrm{C}$. When the temperature of system is $80^{\circ} \mathrm{C}$, there is a substantial decrement in the amount of PPO biocatalyst activity at initial $20 \mathrm{~min}$ it completely becomes inactive after $20 \mathrm{~min}$. There is a moderate slope toward the lower level for POD biocatalyst activity over the entire experiment when the temperature is $40^{\circ} \mathrm{C}$ and $60^{\circ} \mathrm{C}$ and the POD biocatalyst activity reached 20 and $10 \%$, respectively $(60 \mathrm{~min})$. According to the results, the amount of PPO biocatalyst activity is $22 \%$ after $30 \mathrm{~min}$ when the temperature is $80{ }^{\circ} \mathrm{C}$. The activity of PPO and POD biocatalysts at ambient temperature $\left(25^{\circ} \mathrm{C}\right)$ after $60 \mathrm{~min}$ declined to 30 and $40 \%$, respectively. Overally, the heating stability of POD biocatalyst is more than PPO.

\section{Materials and method}

Preparation of samples. Preparation of Green tea leaves was under the responsibility of Iran Tea Research Centre (Lahijan, Iran). To do this research study, Premier-quality tea leaves were chosen and frozen at a very low temperature (i.e., $-25^{\circ} \mathrm{C}$ ) until applied. For carrying out the experimental analysis, the lab based-apparatuses including Domel Tehtnica MillMix 20, HS 18,500 R laboratory centrifuges, Camspec M350 SpectrophotometerManufacturer, digital scale, $\mathrm{pH}$ meter, Checker Plus pH Tester with $0.01 \mathrm{pH}$ Resolution-HI98100 were applied ${ }^{17}$. Required chemical materials such as monopotassium phosphate, catechol, guaiacol, distilled water, hexane, polyvinylpyrrolidone (PVP), hydrogen peroxide (30\%), sodium hydroxide, acetate, citrate, sodium phosphates, glycine, borax, bovine serum albumin were supplied from Sigma-Aldrich (St. Louis, MO, USA) and Merck companies (Darmstadt, Germany) ${ }^{17}$. All chemicals were of analytical grade.

Enzymes extraction. To measure the activity of biocatalysts, their extraction from tea leaves cells seems to be essential. A determined amount of tea leaves was weighed and added into kitchen grinder and was mixed with the solvent. Solvent type is of great importance and buffers are often applied as a chemical solvent for the extraction process of biocatalysts due to the sensitivity of biocatalysts protein structure to $\mathrm{pH}$ alterations. Buffers consisting of acetate and citrate at the $\mathrm{pH}$ value equal to 4 , sodium and potassium phosphate at the $\mathrm{pH}$ value equal to 7 and glycine and borax at the $\mathrm{pH}$ value equal to 9 are applied as solvent. Additionally, distilled water hexane was selected as non-buffer solvents for biocatalysts extraction. The grinding and mixing were simultaneously performed inside the grinder. Within the extraction process, the size of ground tea leaves was between 0.1 to $1 \mathrm{~mm}$. By passing some certain time, it was filtered and centrifuged at a specific operational condition $\left(11,000 \mathrm{rpm}, 4^{\circ} \mathrm{C}, 30 \mathrm{~min}\right)$. To specify the activity, the filtrate was applied as crude biocatalyst after centrifugation. The desirable operational circumstances for biocatalyst extraction and determination of appropriate solvent are $\mathrm{T}=25^{\circ} \mathrm{C}$, buffer $\mathrm{pH} 4,7,9$, buffer-to-tea leave ratio $=3$, Tea leave and solvent contact time $=2 \mathrm{~min}$, Buffer molarity $=0.05 \mathrm{M}$, PVP concentration $=0$ and Tween 80 concentration $=0^{17}$.

Optimization method. RSM procedure (Box-Behnken) is used in this paper to carry out the biocatalysts extraction experiments. The impacts of 7 independent variables consisting of $\mathrm{L} / \mathrm{S}$ ratio, buffer concentration, addition of surfactant (Tween 80), extraction $\mathrm{pH}$, extraction temperature, addition of PVP, and solid-liquid contact time on the amount of PPO/POD biocatalysts activity are aimed to be investigated. Detailed information of the design is represented in Table 4. All experimental conditions are conducted in triplicate. Design-Expert 11 software is applied to evaluate the statistical analysis. 


\begin{tabular}{|l|l|l|l|l|}
\hline \multirow{2}{*}{ Parameter } & \multicolumn{3}{|l|}{ PPO } & \multicolumn{2}{l|}{ POD } \\
\cline { 2 - 5 } & Level & Value & Level & Value \\
\hline Temperature $\left({ }^{\circ} \mathrm{C}\right)$ & -1 & 25 & 0 & 50 \\
\hline Buffer pH & 0 & 7 & -1 & 5 \\
\hline Buffer to mass of tea ratio & 0 & 5 & 0 & 5 \\
\hline Tea and solvent contact time, min & 0 & 10 & 0 & 10 \\
\hline Buff. Conc. (M) & 0 & 0.1 & -1 & 0.05 \\
\hline PVP Conc. (\%) & 1 & 6 & 0 & 3 \\
\hline Tween 80 Conc. (\%) & 1 & 20 & 0 & 5 \\
\hline Error (\%) & 0.03 & & $\cong 0$ & \\
\hline
\end{tabular}

Table 3. Optimized level and value for operation parameters by Design Expert 11.

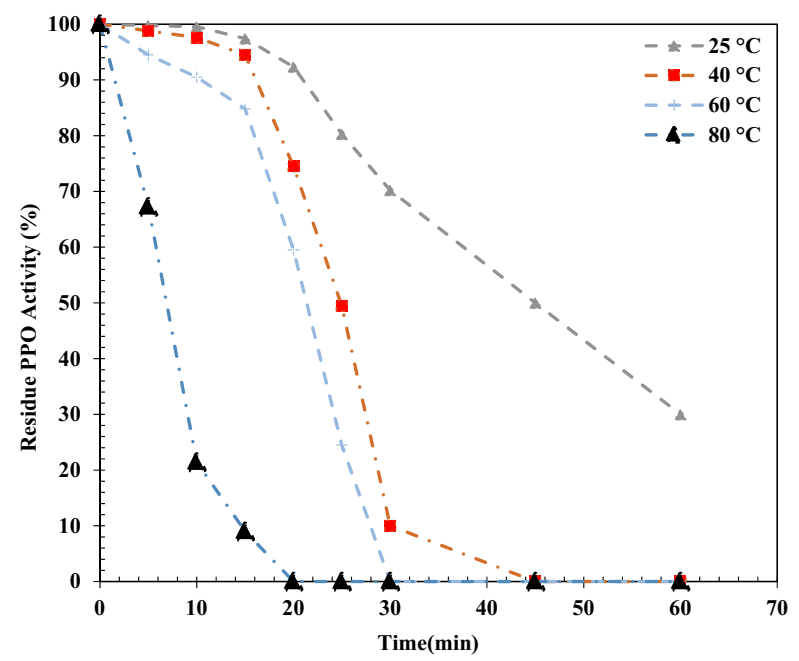

(A)

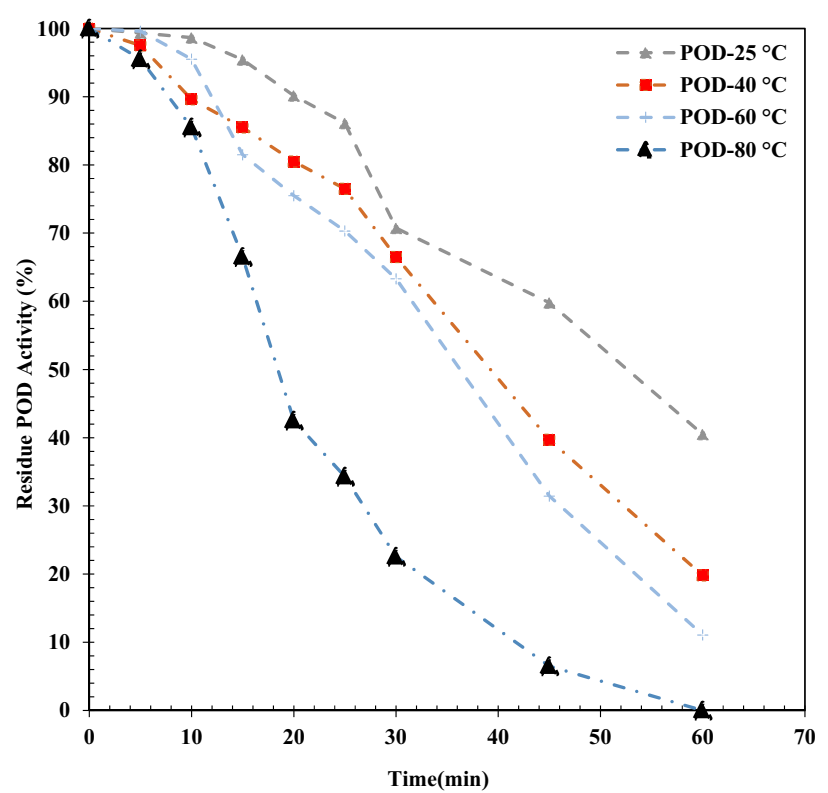

Figure 4. Heat stability of (A) PPO as function of time and temperature, (B) POD as function of time and temperature. 


\begin{tabular}{|l|l|l|l|}
\hline \multirow{2}{*}{ Parameter } & \multicolumn{3}{|l|}{$\begin{array}{l}\text { Coded Factor } \\
\text { and Levels }\end{array}$} \\
\cline { 2 - 5 } & -1 & $\mathbf{0}$ & $\mathbf{1}$ \\
\hline Temperature, ${ }^{\circ} \mathrm{C}$ & 25 & 50 & 75 \\
\hline $\mathrm{pH}$ & 4 & 7 & 9 \\
\hline Buffer to biomass ratio & 3 & 5 & 7 \\
\hline Extraction time, min & 2 & 10 & 20 \\
\hline Buffer content $(\mathrm{M})$ & 0.05 & 0.1 & 0.2 \\
\hline PVP content $(\%)$ & 0 & 3 & 6 \\
\hline Tween 80 content $(\%)$ & 0 & 5 & 20 \\
\hline
\end{tabular}

Table 4. Selection of parameters and their levels for RSM (Box-Behnken).

The measurement of PPO/POD biocatalysts activity. To measure the amount of PPO biocatalyst activity, spectrophotometric method is applied ${ }^{45}$. Catechol solution has been applied as substrate. The sample (cuvette) contains $1.45 \mathrm{ml}$ of $100 \mathrm{mM}$ potassium phosphate buffer with $\mathrm{pH}$ of $6.8,0.5 \mathrm{ml}$ of $100 \mathrm{mM}$ catechol solution, and $0.05 \mathrm{ml}$ of the enzyme solution. The blank sample consists of only $2 \mathrm{ml}$ of substrate solution. The final substrate concentration in the $2 \mathrm{~mL}$ assay is $25 \mathrm{mM}$. The assay mixture is permitted to be incubated for $3 \mathrm{~min}$ at room temperature in a disposable polystyrene cuvette ${ }^{52}$. One unit of biocatalyst activity is described as the amount of biocatalyst that results in an alteration in the absorbance of 0.001 per min. PPO activity is assayed in triplicate measurements. Alteration in absorption as a function of time is recorded for 2 min at the ambient temperature. Reaction 3 takes place during assay. As illustrated, the production of this reaction product is benzoquinone, which its absorption coefficient is $1010 \mathrm{M}^{-1} \mathrm{~cm}^{-145,52}$.

Catechol<smiles>CCCOc1ccccc1O</smiles>

$+\frac{1}{2} \mathrm{O}_{2} \stackrel{\text { PPO }}{\Longrightarrow}$

Benzoquinone

POD biocatalyst activity is measured applying guaiacol substrate in the presence of hydrogen peroxide at $470 \mathrm{~nm}$. The sample cuvette contains $2.70 \mathrm{~mL}$ of $100 \mathrm{mM}$ potassium phosphate buffer with $\mathrm{pH}$ value $6.8,0.15 \mathrm{~mL}$ of $4 \%$ guaiacol, $0.10 \mathrm{~mL}$ of $3 \%$ hydrogen peroxide, and $0.05 \mathrm{ml}$ crude biocatalyst ${ }^{52}$. The $4 \%$ guaiacol is provided by dispensing $0.4 \mathrm{~mL}$ guaiacol in $9.6 \mathrm{~mL}$ of deionized water and shaken severely to manufacture an emulsion before application. After incubation, POD activity is monitored at $470 \mathrm{~nm}$ for $2 \mathrm{~min}$ at room temperature. The reaction product is biphenoquinone with the absorption coefficient of $26,600 \mathrm{M}^{-1} \cdot \mathrm{cm}^{-145}$ :

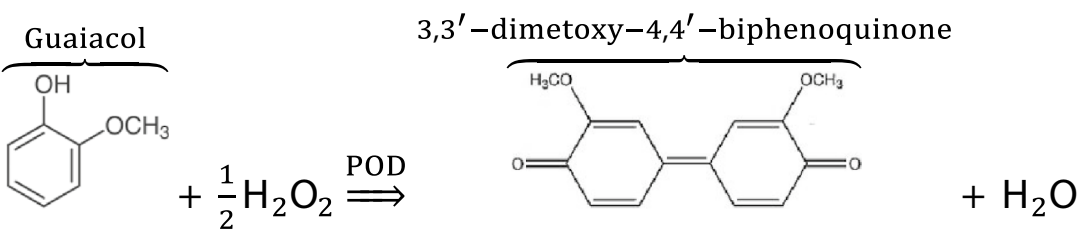

The variation of concentration is able to be predicted on the basis of alteration in the amount of absorbed light. According to Lambert-Beer law, concentration is in direct relationship with absorption value in a wavelength and reverse relationship with thickness of cuvette as the follows ${ }^{53,54}$ :

$$
C=\frac{A}{\varepsilon d}
$$

In the abovementioned equation, $\mathrm{A}, \mathrm{d}$ and $\varepsilon$ are respectively interpreted as the amount of absorption, cuvette thickness and molar absorptivity. To evaluate the amounts of PPO/POD activity, the cuvette consisting of biocatalyst was located in the spectrophotometer for $30 \mathrm{~s}$ and wavelength alteration with time is recorded. Equation 6 is applied to compute PPO/POD activity ${ }^{53,54}$ :

$$
U=\frac{\Delta C \times V \times 10^{6}}{\Delta t}=\frac{\Delta A \times V \times 10^{6}}{\varepsilon \times d \times \Delta t}
$$

In this equation, $U, V$ and $t$ are denoted as the biocatalyst activity, the reaction media volume and the reaction time. 


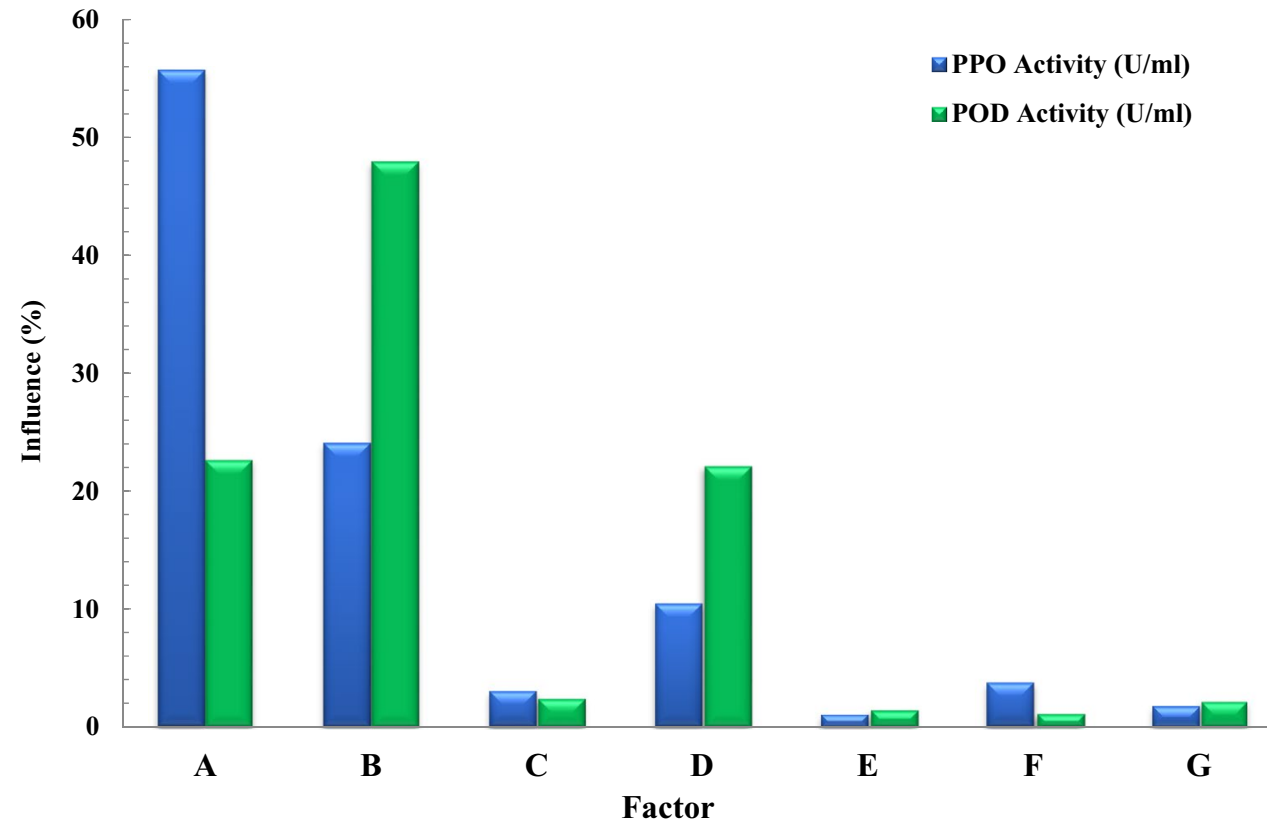

Figure 5. Percentage contribution of each variables on PPO and POD activities.

Protein determination. The concentration of protein is determined on the basis of the dye-binding method of Bradford, with bovine serum albumin as standard ${ }^{55}$. The value of obtained absorption is evaluated by graphic interpolation on a calibration curve at $595 \mathrm{~nm}$.

As shown in Fig. 5, the effect of each of the experimental parameters on the activity of POD and PPO enzymes is determined. The maximum effect on the activity of POD and PPO biocatalysts is the $\mathrm{pH}$ and temperature parameters, respectively.

Evaluation of the heat stability of PPO/POD biocatalysts. Thermal inactivation experiments are carried out in a water bath at constant temperatures of $25,40,60$ and $80^{\circ} \mathrm{C}$. Samples are exposed to each temperature for 0-60 $\mathrm{min}$ and the remaining activity is assayed at $5 \mathrm{~min}$ intervals in triplicate. The operational circumstances of PPO/POD biocatalysts extraction applied in thermal inactivation experiment are presented in Table 3.

\section{Conclusion}

Iranian tea leaves are well perceived to possess great potential illustrate PPO and POD activity. RSM (BoxBehnken) method has been employed in this paper to optimize large number of parameters through minimum required tests. By implementing the analysis, final optimum states of extraction factors were obtained. The optimum operational conditions for efficient $\mathrm{PPO}$ and POD biocatalysts extraction/activity were; $\mathrm{T}=25^{\circ} \mathrm{C}, \mathrm{pH} 7$, buffer molarity $=0.1 \mathrm{M}$, buffer/tea leaves ratio $=5$, contact time $=10 \mathrm{~min}$, and presence of $6 \% \mathrm{PVP}$ and $20 \%$ Tween 80 for $\mathrm{PPO}$ and $\mathrm{T}=50^{\circ} \mathrm{C}, \mathrm{pH} 5$, buffer molarity $=0.05 \mathrm{M}$, buffer $/$ tea leaves ratio $=5$, contact time $=10 \mathrm{~min}$, and the existence of 3\% PVP and 5\% Tween 80 for POD. It was well understood from the research that PPO extracted from tea has the ability of activation in basic media ( $\mathrm{pH} 9$ ). According to the optimization outcomes, the most momentous operational/functional parameters for PPO extraction were temperature (55.67\%), $\mathrm{pH}(24.07 \%)$ and addition of Tween 80 (1.79\%), while for POD biocatalyst they were $\mathrm{pH}(47.89 \%)$, addition of surfactant $(0.01 \%)$, and temperature $(22.70 \%)$. The obtained outcomes from thermal inactivation implied that POD biocatalyst is more resistant compared to PPO. PPO biocatalyst entirely lost its activity after $45 \mathrm{~min}$ for all isotherms (other than ambient temperature); while POD maintained its activity even at the temperature of $80{ }^{\circ} \mathrm{C}(6 \%$ at $45 \mathrm{~min})$.

\section{Supplementary file}

Desirability contours of the effect of seven parameters on PPO and POD enzymes activity as well as the calculated activity for PPO and POD enzymes are reported in Supplementary file.

Received: 25 July 2020; Accepted: 1 February 2021

Published online: 18 February 2021

\section{References}

1. Jun, L. Y. et al. An overview of immobilized enzyme technologies for dye and phenolic removal from wastewater. J. Environ. Chem. Eng. 7, 102961 (2019). 
2. Silva, M. C. et al. Immobilization of soybean peroxidase on silica-coated magnetic particles: a magnetically recoverable biocatalyst for pollutant removal. RSC Adv. 6, 83856-83863 (2016).

3. Abdollahi, K., Yazdani, F., Panahi, R. \& Mokhtarani, B. Biotransformation of phenol in synthetic wastewater using the functionalized magnetic nano-biocatalyst particles carrying tyrosinase. 3 Biotech 8, 419 (2018).

4. Unuofin, J. O., Okoh, A. I. \& Nwodo, U. U. Aptitude of oxidative enzymes for treatment of wastewater pollutants: a laccase perspective. Molecules 24, 2064 (2019).

5. Ceni, G. C. et al. Oxidases from mate tea leaves (Ilex paraguariensis): extraction optimization and stability at low and high temperatures. Bioprocess Biosyst. Eng. 31, 541-550 (2008).

6. Derardja, A. E., Pretzler, M., Kampatsikas, I., Barkat, M. \& Rompel, A. Purification and characterization of latent polyphenol oxidase from apricot (Prunus armeniaca L.). J. Agric. Food Chem. 65, 8203-8212 (2017).

7. Sun, H.-J. et al. Purification and characterization of polyphenol oxidase from rape flower. J. Agric. Food Chem. 60, 823-829 (2012).

8. Palma-Orozco, G., Marrufo-Hernández, N. A., Sampedro, J. G. \& Nájera, H. Purification and partial biochemical characterization of polyphenol oxidase from mango (Mangifera indica cv. Manila). J. Agric. Food Chem. 62, 9832-9840 (2014).

9. Jun, L. Y. et al. Immobilization of peroxidase on functionalized MWCNTs-buckypaper/polyvinyl alcohol nanocomposite membrane. Sci. Rep. 9, 1-15 (2019).

10. Reheman, A. et al. optimization of extraction technology of Majun Mupakhi ela and its effect on Hydrocortisone-induced Kidney Yang Deficiency in Mice. Sci. Rep. 9, 1-14 (2019).

11. Shen, S. et al. Optimization of horseradish peroxidase catalytic degradation for 2-methyl-6-ethylaniline removal using response surface methodology. Water 11, 1093 (2019).

12. Ghadiri, M., Hemmati, A., Nakhjiri, A. T. \& Shirazian, S. Modelling tyramine extraction from wastewater using a non-dispersive solvent extraction process. Environ. Sci. Pollut. Res. 2020, 1-9 (2020).

13. Guo, L., Ma, Y., Shi, J. \& Xue, S. The purification and characterisation of polyphenol oxidase from green bean (Phaseolus vulgaris L.). Food Chem. 117, 143-151. https://doi.org/10.1016/j.foodchem.2009.03.088 (2009).

14. Pinto, M. S. T., Siqueira, F. P., Oliveira, A. E. A. \& Fernandes, K. V. S. A wounding-induced PPO from cowpea (Vigna unguiculata) seedlings. Phytochemistry 69, 2297-2302. https://doi.org/10.1016/j.phytochem.2008.06.003 (2008).

15. Batista, K. A., Batista, G. L. A., Alves, G. L. \& Fernandes, K. F. Extraction, partial purification and characterization of polyphenol oxidase from Solanum lycocarpum fruits. J. Mol. Catal. B Enzym. 102, 211-217. https://doi.org/10.1016/j.molcatb.2014.02.017 (2014).

16. Wuyts, N., De Waele, D. \& Swennen, R. Extraction and partial characterization of polyphenol oxidase from banana (Musa acuminata Grande naine) roots. Plant Physiol. Biochem. 44, 308-314. https://doi.org/10.1016/j.plaphy.2006.06.005 (2006).

17. Koohi, S. et al. Extraction of oxidative enzymes from green tea leaves and optimization of extraction conditions. Chem. Eng. Technol. 43, 2548-2556 (2020).

18. Hamid, M. \& Khalil ur, R. Potential applications of peroxidases. Food Chem. 115, 1177-1186. https://doi.org/10.1016/j.foodc hem.2009.02.035 (2009)

19. Chanwun, T., Muhamad, N., Chirapongsatonkul, N. \& Churngchow, N. Hevea brasiliensis cell suspension peroxidase: purification, characterization and application for dye decolorization. AMB Express 3, 14-14. https://doi.org/10.1186/2191-0855-3-14 (2013).

20. Moore, B. M. \& Flurkey, W. H. Sodium dodecyl sulfate activation of a plant polyphenoloxidase. Effect of sodium dodecyl sulfate on enzymatic and physical characteristics of purified broad bean polyphenoloxidase. J. Biol. Chem. 265, 4982-4988 (1990).

21. Wakamatsu, K. \& Takahama, U. Changes in peroxidase activity and in peroxidase isozymes in carrot callus. Physiol. Plant. 88, 167-171. https://doi.org/10.1111/j.1399-3054.1993.tb01774.x (1993).

22. Babanezhad, M., Masoumian, A., Nakhjiri, A. T., Marjani, A. \& Shirazian, S. Influence of number of membership functions on prediction of membrane systems using adaptive network based fuzzy inference system (ANFIS). Sci. Rep. 10, 16110. https://doi. org/10.1038/s41598-020-73175-0 (2020).

23. Marjani, A., Nakhjiri, A. T., Adimi, M., Jirandehi, H. F. \& Shirazian, S. Effect of graphene oxide on modifying polyethersulfone membrane performance and its application in wastewater treatment. Sci. Rep. https://doi.org/10.1038/s41598-020-58472-y (2020).

24. Marjani, A., Nakhjiri, A. T., Taleghani, A. S. \& Shirazian, S. Mass transfer modeling CO2 absorption using nanofluids in porous polymeric membranes. J. Mol. Liq. https://doi.org/10.1016/j.molliq.2020.114115 (2020).

25. Marjani, A., Taghvaie Nakhjiri, A., Adimi, M., Fathinejad Jirandehi, H. \& Shirazian, S. Modification of polyethersulfone membrane using MWCNT-NH2 nanoparticles and its application in the separation of azeotropic solutions by means of pervaporation. PLoS ONE 15, e0236529 (2020).

26. Nakhjiri, A. T. \& Heydarinasab, A. Efficiency evaluation of novel liquid potassium lysinate chemical solution for $\mathrm{CO} 2 \mathrm{molecular}$ removal inside the hollow fiber membrane contactor: Comprehensive modeling and CFD simulation. J. Mol. Liq. https://doi. org/10.1016/j.molliq.2019.111561 (2019).

27. Nakhiiri, A. T. \& Heydarinasab, A. Computational simulation and theoretical modeling of CO2 separation using EDA, PZEA and PS absorbents inside the hollow fiber membrane contactor. J. Ind. Eng. Chem. 78, 106-115 (2019).

28. Nakhjiri, A. T., Heydarinasab, A., Bakhtiari, O. \& Mohammadi, T. Modeling and simulation of $\mathrm{CO} 2$ separation from $\mathrm{CO} 2 / \mathrm{CH} 4$ gaseous mixture using potassium glycinate, potassium argininate and sodium hydroxide liquid absorbents in the hollow fiber membrane contactor. J. Environ. Chem. Eng. 6, 1500-1511 (2018).

29. Shirazian, S., Nakhjiri, A. T., Heydarinasab, A. \& Ghadiri, M. Theoretical investigations on the effect of absorbent type on carbon dioxide capture in hollow-fiber membrane contactors. PLoS ONE https://doi.org/10.1371/journal.pone.0236367 (2020).

30. Albadarin, A. B. et al. Activated lignin-chitosan extruded blends for efficient adsorption of methylene blue. Chem. Eng. J. 307, 264-272. https://doi.org/10.1016/j.cej.2016.08.089 (2017).

31. Marjani, A., Soltani, R., Pishnamazi, M., Rezakazemi, M. \& Shirazian, S. Functionalized pollen-like mesoporous silica for Cr (VI) removal. Microporous Mesoporous Mater. 310, 110531 (2021).

32. Soltani, R., Marjani, A., Hosseini, M. \& Shirazian, S. Meso-architectured siliceous hollow quasi-capsule. J Colloid Interfaces Sci. 570, 390-401 (2020).

33. Soltani, R., Marjani, A., Moguei, M. R. S., Rostamia, B. \& Shirazian, S. Novel diamino-functionalized fibrous silica submicro-spheres with a bimodal-micro-mesoporous network: Ultrasonic-assisted fabrication, characterization, and their application for superior uptake of Congo red. J. Mol. Liq. 294, 111617 (2019).

34. Soltani, R., Marjani, A. \& Shirazian, S. Facile one-pot synthesis of thiol-functionalized mesoporous silica submicrospheres for Tl (I) adsorption: isotherm, kinetic and thermodynamic studies. J. Hazard. Mater. 371, 146-155 (2019).

35. Soltani, R., Marjani, A. \& Shirazian, S. Shell-in-shell monodispersed triamine-functionalized $\mathrm{SiO} 2$ hollow microspheres with micro-mesostructured shells for highly efficient removal of heavy metals from aqueous solutions. J. Environ. Chem. Eng. 7, 102832 (2019).

36. Soltani, R., Marjani, A. \& Shirazian, S. Novel mesoporous crumpled paper-like silica balls. Mater. Lett. 281, 128230 (2020).

37. Soltani, R., Marjani, A., Soltani, R. \& Shirazian, S. Hierarchical multi-shell hollow micro-meso-macroporous silica for cr (Vi) adsorption. Sci. Rep. 10, 1-12 (2020).

38. Shirazian, S. \& Ashrafizadeh, S. N. Near-critical extraction of the fermentation products by membrane contactors: A mass transfer simulation. Ind. Eng. Chem. Res. 50, 2245-2253. https://doi.org/10.1021/ie101343r (2011).

39. Khajeh, M., Kaykhaii, M. \& Sharafi, A. Application of PSO-artificial neural network and response surface methodology for removal of methylene blue using silver nanoparticles from water samples. J. Ind. Eng. Chem. 19, 1624-1630 (2013). 
40. Jain, A., Jayaraman, S., Singh, G. \& Srinivasan, M. P. Single step peroxidase extraction and oxidation of highly concentrated ethanol and phenol aqueous solutions using supercritical carbon dioxide. J. Supercrit. Fluids 116, 209-214. https://doi.org/10.1016/j.supfl u.2016.05.021 (2016).

41. Panadare, D. C. \& Rathod, V. K. Extraction of peroxidase from bitter gourd (Momordica charantia) by three phase partitioning with dimethyl carbonate (DMC) as organic phase. Process Biochem. 61, 195-201. https://doi.org/10.1016/j.procbio.2017.06.028 (2017).

42. Khajeh, M. \& Gharan, M. Separation of organic acid compounds from biological samples by zinc oxide nanoparticles-chitosan using genetic algorithm based on response surface methodology and artificial neural network. J. Chemom. 28, 539-547 (2014).

43. Imm, J-Y. \& Kim, S.-C. Convenient partial purification of polyphenol oxidase from apple skin by cationic reversed micellar extraction. Food Chem. 113, 302-306. https://doi.org/10.1016/j.foodchem.2008.07.028 (2009).

44. Thirumalaikumarasamy, D., Shanmugam, K. \& Balasubramanian, V. Corrosion performance of atmospheric plasma sprayed alumina coatings on AZ31B magnesium alloy under immersion environment. J. Asian Ceram. Soc. 2, 403-415 (2014).

45. Furumo, N. C. \& Furutani, S. Simple method for assaying total protein, polyphenol oxidase and peroxidase activity from 'Kaimana' litchi chinensis sonn. J. Hawaiian Pac. Agric. 15, 1-4 (2008).

46. Yue-Ming, J., Zauberman, G. \& Fuchs, Y. Partial purification and some properties of polyphenol oxidase extracted from litchi fruit pericarp. Postharvest Biol. Technol. 10, 221-228. https://doi.org/10.1016/S0925-5214(96)01404-4 (1997).

47. Rudra Shalini, G., Shivhare, U. S. \& Basu, S. Thermal inactivation kinetics of peroxidase in mint leaves. J. Food Eng. 85, 147-153. https://doi.org/10.1016/j.jfoodeng.2007.07.010 (2008).

48. Paul, B. \& Gowda, L. R. Purification and characterization of a polyphenol oxidase from the seeds of field bean (Dolichos lablab). J. Agric. Food Chem. 48, 3839-3846. https://doi.org/10.1021/jf000296s (2000).

49. Ghacham, A. B., Pasquier, L.-C., Cecchi, E., Blais, J.-F. \& Mercier, G. CO 2 sequestration by mineral carbonation of steel slags under ambient temperature: parameters influence, and optimization. Environ. Sci. Pollut. Res. 23, 17635-17646 (2016).

50. Serrano-Martínez, A., Fortea, M. I., del Amor, F. M. \& Núñez-Delicado, E. Kinetic characterisation and thermal inactivation study of partially purified red pepper (Capsicum annuum L.) peroxidase. Food Chem. 107, 193-199. https://doi.org/10.1016/j.foodc hem.2007.08.028 (2008).

51. Mayer, A. M. Polyphenol oxidases in plants and fungi: Going places? A review. Phytochemistry 67, 2318-2331. https://doi. org/10.1016/j.phytochem.2006.08.006 (2006).

52. Marjani, A., Zare, M. H., Sadeghi, M. H., Shirazian, S. \& Ghadiri, M. Synthesis of alginate-coated magnetic nanocatalyst containing high-performance integrated enzyme for phenol removal. J. Environ. Chem. Eng. 2020, 104884 (2020).

53. Bergmeyer, H. U. Methods of Enzymatic Analysis, Methods of Enzymatic Analysis: Volume 3: Metabolites 3: Lipids, Amino Acids and Related Compounds (Wiley, New York, 1985).

54. Pundir, C. S. Enzyme Nanoparticles: Preparation, Characterisation, Properties and Applications (Elsevier Science, Amsterdam, 2015).

55. Bradford, M. M. A rapid and sensitive method for the quantitation of microgram quantities of protein utilizing the principle of protein-dye binding. Anal. Biochem. 72, 248-254. https://doi.org/10.1016/0003-2697(76)90527-3 (1976).

\section{Author contributions}

R.P.: Conceptualization, methodology, software, validation, formal analysis. A.K.: Conceptualization, resources. M.H.Z.: Supervision, writing-reviewing and editing, software, validation. M.H.S.: Conceptualization, resources, experiments. A.M.: Supervision, writing-review, funding, revision.

\section{Competing interests}

The authors declare no competing interests.

\section{Additional information}

Supplementary Information The online version contains supplementary material available at https://doi. org/10.1038/s41598-021-83232-x.

Correspondence and requests for materials should be addressed to A.M.

Reprints and permissions information is available at www.nature.com/reprints.

Publisher's note Springer Nature remains neutral with regard to jurisdictional claims in published maps and institutional affiliations.

Open Access This article is licensed under a Creative Commons Attribution 4.0 International License, which permits use, sharing, adaptation, distribution and reproduction in any medium or format, as long as you give appropriate credit to the original author(s) and the source, provide a link to the Creative Commons licence, and indicate if changes were made. The images or other third party material in this article are included in the article's Creative Commons licence, unless indicated otherwise in a credit line to the material. If material is not included in the article's Creative Commons licence and your intended use is not permitted by statutory regulation or exceeds the permitted use, you will need to obtain permission directly from the copyright holder. To view a copy of this licence, visit http://creativecommons.org/licenses/by/4.0/.

(C) The Author(s) 2021 